\title{
Integrated uppermost Campanian-Maastrichtian calcareous nannofossil and foraminiferal biostratigraphic zonation of the northwestern margin of Australia
}

\author{
R. W. HOWE ${ }^{1,2}$, R. J. CAMPBELL ${ }^{1} \&$ J. P. REXILIUS ${ }^{3}$ \\ ${ }^{1}$ School of Earth \& Geographical Sciences, The University of Western Australia, 35 Stirling Highway, Crawley, WA 6009, Australia \\ (e-mail: rhowe@geol.uwa.edu.au,rcampbel@geol.uwa.edu.au) \\ ${ }^{2}$ Current address: Energy \& Geoscience Institute, The University of Utah, 423 Wakara Way, Suite 300, Salt Lake City, UT 84108, USA \\ (e-mail: rhowe@egi.utah.edu) \\ ${ }^{3}$ International Stratigraphic Consultants Pty Ltd, 73 Rule St., North Fremantle, WA 6159, Australia (e-mail: jrex@iscbiostrat.com)
}

\begin{abstract}
During the latest Campanian-Maastrichtian the northwestern Australian margin was situated between the cool-water Austral Province to the south and the warm-water Tethyan Province to the north. The transitional nature of calcareous microfossil assemblages on the margin makes application of Tethyan biostratigraphic zonation schemes awkward, as many marker-species are missing or have different ranges. This study presents an integrated uppermost Campanian-Maastrichtian calcareous microfossil zonation based on two Ocean Drilling Program (ODP) holes on the Exmouth Plateau and eight petroleum exploration wells from the Vulcan Sub-basin. The zonation is refined and revised from the previously unpublished KCN (nannofossils), KPF (planktonic foraminifera), KBF (benthonic foraminifera) and KCCM (composite nannofossil and planktonic foraminifera) zonations, which are commonly used for petroleum exploration wells drilled on the northwestern margin. Revision of the zonations has highlighted a major Upper Campanian to lower Upper Maastrichtian disconformity on the Exmouth Plateau, which went largely unnoticed in previous examinations of the ODP material, but had been recorded previously elsewhere on the northwestern margin. The duration of the disconformity in the Vulcan Sub-basin is unclear, since intervals of the succession may be condensed in this area. $J$. Micropalaeontol. 22(1): 29-62, July 2003.
\end{abstract}

\section{INTRODUCTION}

During the mid-Late Cretaceous, calcareous nannofossil and foraminiferal assemblages on the Western Australian margin (Fig. 1) were differentiated into a high southern-latitude Austral Province, with cool surface-water masses, and a low southernlatitude Tethyan Province with warm surface-water masses (Fig. 2; Rexilius, 1984; Shafik, 1990, 1993; Bralower \& Siesser, 1992; Huber, 1992; Wonders, 1992; Watkins et al., 1996). At intermediate latitudes, a Transitional Province existed, with temperate surface waters (Shafik, 1990, 1993; Huber, 1992). Many species of calcareous nannofossil and planktonic foraminifera were cosmopolitan and were present in all three provinces, while others were more temperature-sensitive and confined to a single province. The boundaries between the provinces are diffuse and moved north and south through time, according to global climate, ocean-current circulation, and the position of the Australian continent, which rotated anticlockwise and moved slowly north throughout the Cretaceous (Audley-Charles et al., 1988; Scotese et al., 1988; Metcalfe, 1996).

A global cooling trend commenced during the Late Campanian and continued into the Maastrichtian (Huber et al., 1995; Clarke \& Jenkyns, 1999; Premoli Silva \& Sliter, 1999). Two brief warming events punctuated this cooling trend, during the midMaastrichtian, and again in the very latest Maastrichtian (Barrera, 1994; Huber et al., 1995; Watkins et al., 1996; Barrera et al., 1997). The Western Australian margin spanned c. $20^{\circ}$ of palaeolatitude during the Maastrichtian, with the Perth and Southern Carnarvon Basins in the south clearly having Austral affinities and the northwestern margin having Transitional affinities (Rexilius, 1984; Shafik 1990, 1993). Maastrichtian strata in Papua New Guinea and northeastern India show strong Tethyan affinities (Shafik, 1990; Chungkham \& Jafar, 1998; R. W. Howe, unpublished data).

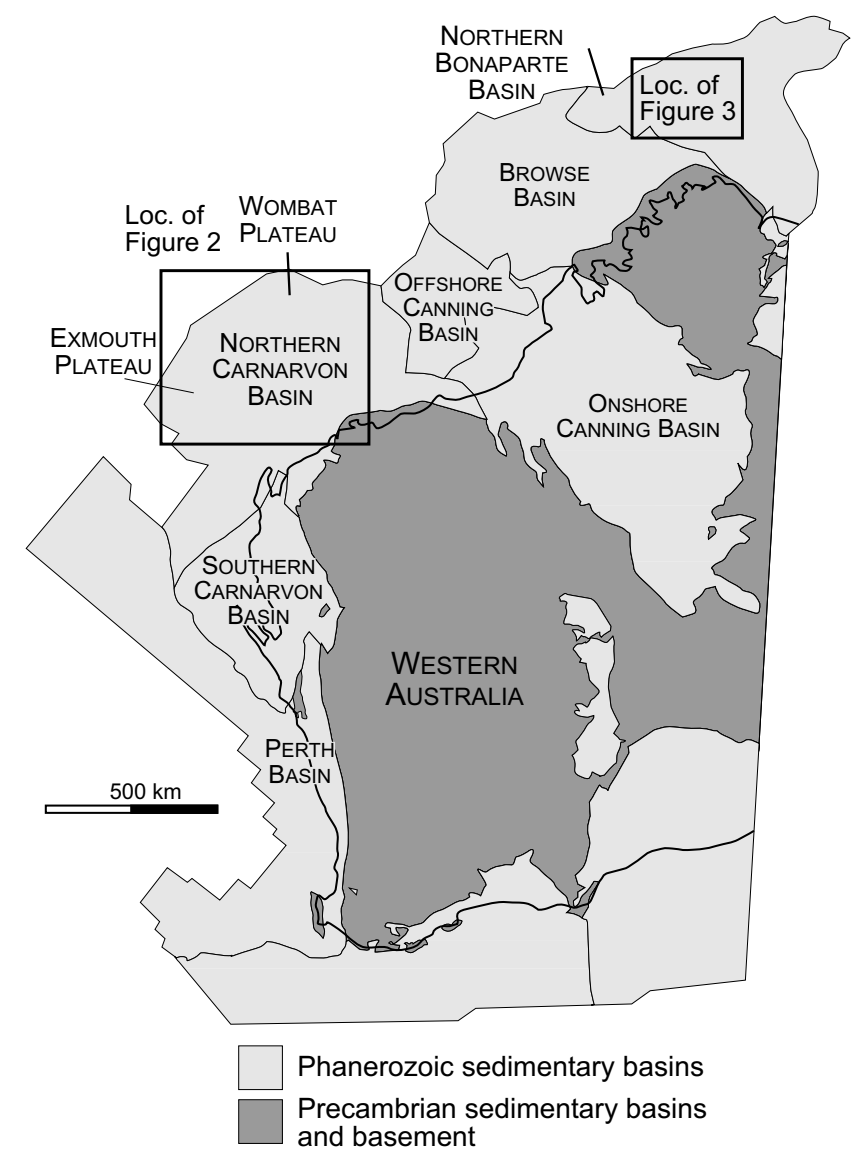

Fig. 1. Location of the studied areas. 


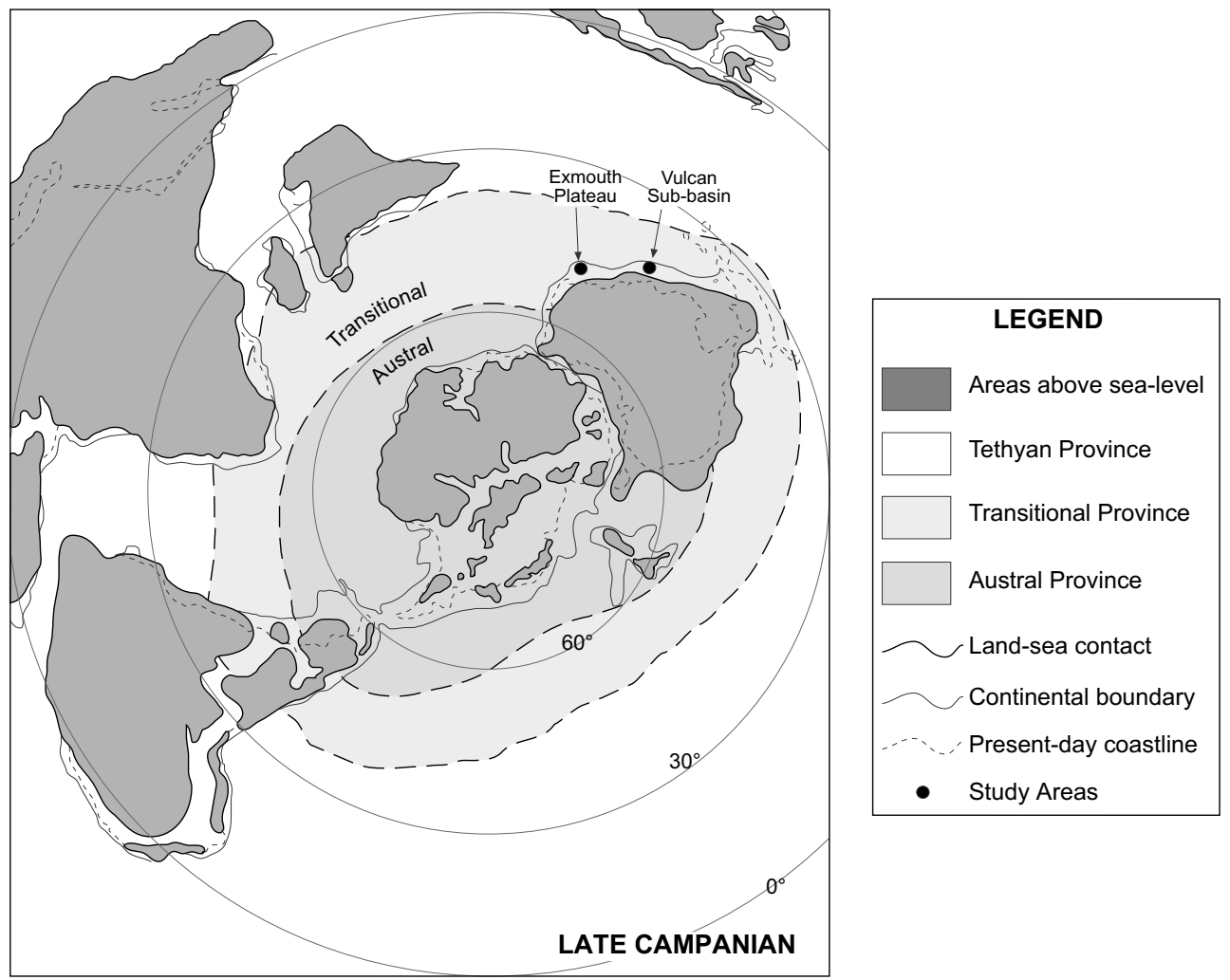

Fig. 2. Palaeogeographical reconstruction for the Late Campanian-Maastrichtian, showing the approximate locations of the studied sections and the inferred palaeobiogeographical boundaries between Austral, Transitional and Tethyan Realms (from Huber, 1992).

This biogeographical differentiation has made biostratigraphic zonation of the Western Australian margin relatively simple during warmer periods where Tethyan influence is greatest (e.g. the latest Albian to Late Santonian) and Tethyan zonations (e.g. Sissingh, 1977 for nannofossils, and Robaszynski \& Caron, 1995 for planktonic foraminifera) can be readily applied. During times of cooler surface-water influence (e.g. Aptian to Albian and Campanian to Maastrichtian) Tethyan zonations are more difficult to apply (particularly for planktonic foraminifera), as many index species do not occur, or have different ranges compared to other parts of the world. Bralower \& Siesser (1992), Wonders (1992) and Petrizzo (2000) discuss the difficulties of applying both calcareous nannofossil and planktonic foraminiferal Tethyan zonations to the northwestern Australian margin. High-latitude Austral Province zonations (e.g. Watkins et al., 1996 for calcareous nannofossils; Huber, 1991 for planktonic foraminifera) have not been applied to the Western Australian margin, although they would probably be applicable to assemblages in the Perth Basin on the southwestern margin, where Rexilius (1984) records assemblages with strong Austral affinities.

Since the early 1970s studies on the Western Australian margin have either applied local industrial zonations, such as the unpublished KCCM composite foraminiferal and calcareous nannofossil zonation of J. P. Rexilius, which was developed in the early 1980s and the planktonic foraminiferal zonation of Wright \& Apthorpe $(1976,1995)$, or they have used a combination of local and cosmopolitan nannofossil events (e.g. Shafik,
1993). Petroleum exploration companies operating on the northwestern margin of Australia typically employ the KCCM zonation to correlate mid-Upper Cretaceous strata. This zonal scheme uses calcareous nannofossil and foraminiferal events together to provide high-resolution subdivisions, but as the biostratigraphic events that make up the zonation are unpublished, it has been difficult to correlate the KCCM zonation to more widely used global calcareous nannofossil and planktonic foraminiferal zonation schemes (such as the recent UC nannofossil zonation of Burnett, 1998). The present study documents the Maastrichtian part of the KCCM zonation, and introduces a refined version of the zonation, allowing up-to-date correlation of the zonation (and the many petroleum exploration wells on the northwestern Australian margin that are documented in terms of it) to the international chronostratigraphic scale.

\section{STUDY AREA}

\section{Tectonic history}

The northwestern Australian margin (see Fig. 1) developed as a passive margin following Middle-Late Jurassic rifting of the Gondwana supercontinent (Audley-Charles, 1988; Powell et al., 1988; Baillie et al., 1994; Metcalfe, 1996). Prior to breakup, the northwestern Australian margin was a passive margin on the northeastern edge of Gondwanaland, facing the southern Tethys ocean (von Rad et al., 1992). The onset of rifting and separation of microcontinents from the northwestern Australian margin has been dated as Callovian (Veevers \& Powell, 1990), with 


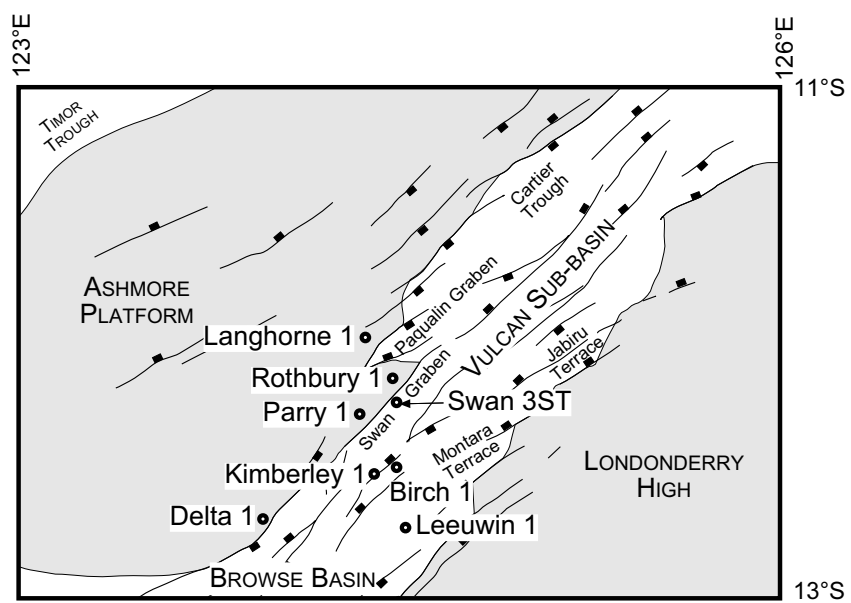

Fig. 3. Location of wells studied in the Browse Basin and Vulcan Sub-basin (after Kennard et al., 1999).

more recent work suggesting an Oxfordian/Kimmeridgian age (Müller et al., 1998). The rifting that had commenced at the northern margin of eastern Gondwanaland propagated southward, separating Greater India from western Australia during the Valanginian, and creating the eastern Indian Ocean (Veevers \& Powell, 1990; Holmes \& Watkins, 1992; von Rad \& Bralower, 1992). By the Maastrichtian (c. 71-65 Ma in the time-scale of Gradstein et al., 1994), the northwestern margin of Australia lay on the eastern side of a mature ocean (see Fig. 2; von Rad et al., 1992), at a palaeolatitude of $30-45^{\circ} \mathrm{S}$ (Audley-Charles et al., 1988; Struckmeyer et al., 1990; Veevers et al., 1991; Pospichal \& Bralower, 1992).

\section{Geological setting}

The northwestern margin of Western Australia is segmented into four major sedimentary basins bound by Proterozoic fracture systems: the Bonaparte, Browse, Canning and Carnarvon Basins (O'Brien et al., 1999). This study focuses on the Vulcan Sub-basin in the western Bonaparte Basin (Figs 1, 3), and the Exmouth Plateau in the western part of the Northern Carnarvon Basin (Figs 1, 4). The Vulcan Sub-basin is an elongate (about $270 \mathrm{~km}$ long and $80 \mathrm{~km}$ wide), northeast-southwest-trending Mesozoic depocentre, comprising a series of horst blocks, grabens and terraces (Kennard et al., 1999). It has faultbound margins with the Ashmore Platform to the west and the Londonderry High to the east. The structural history of the region is complex, including two extensional events in the Palaeozoic, a compressional event in the Late Triassic and further extension in the Jurassic (O'Brien et al., 1993; Kennard et al., 1999). The Exmouth Plateau is a large, marginal plateau bounded to the east by the Kangaroo Syncline, which separates it from the Beagle Basin, Dampier Sub-basin and Barrow Sub-basin. It is about $600 \mathrm{~km}$ long and $300-400 \mathrm{~km}$ wide, and is bounded to the north, west and south by the oceanic crust of the Argo, Gascoyne and Cuvier Abyssal Plains, respectively (Exon et al., 1992a).

\section{Stratigraphic framework}

Exmouth Plateau. Following Early Cretaceous rifting and the development of a mature ocean on Australia's northwestern

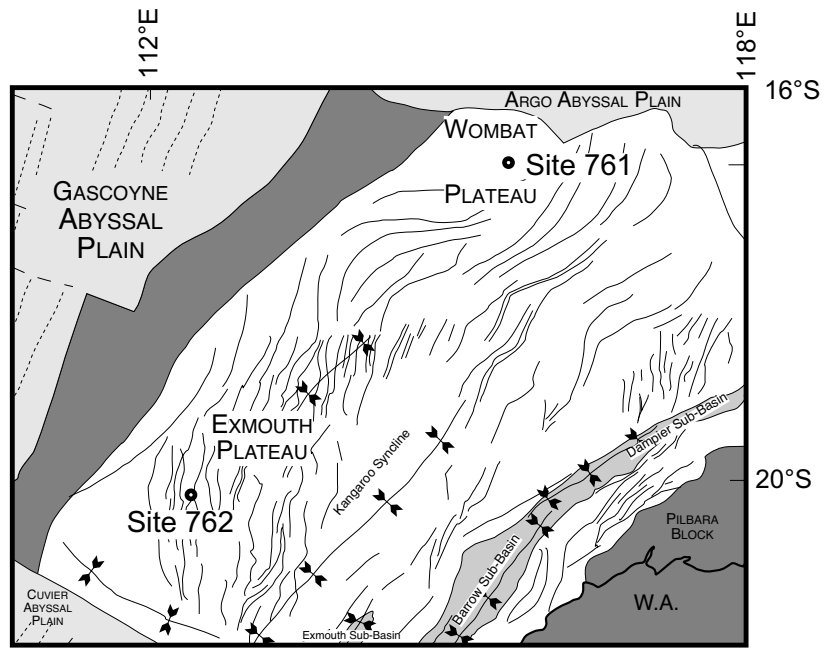

Fig. 4. Location of ODP sites 761 and 762 on the Wombat and Exmouth Plateaus. Structural elements after AGSO North West Shelf Study Group (1994).

margin, the Exmouth Plateau was far from detrital sources, so input of siliciclastic sediment declined (Exon et al., 1992a). As a result, Late Cretaceous and Palaeogene strata are thin and condensed, and consist of chalk and marl successions (Fig. 5). The sediments are typically bioturbated, light green-grey and light brown clayey nannofossil chalks containing foraminifera and ostracods (Haq et al., 1990a, b, Exon et al., 1992b). Huang et al. (1992) related cyclic light and dark chalk horizons to orbital changes which controlled the alternation of two prevailing climate regimes in the area. Sedimentation rates at Site 762 were estimated at $14.1 \mathrm{~m} \mathrm{Ma}^{-1}$ by Golovchenko et al. (1992). Bathyal water depths are interpreted for the Exmouth Plateau

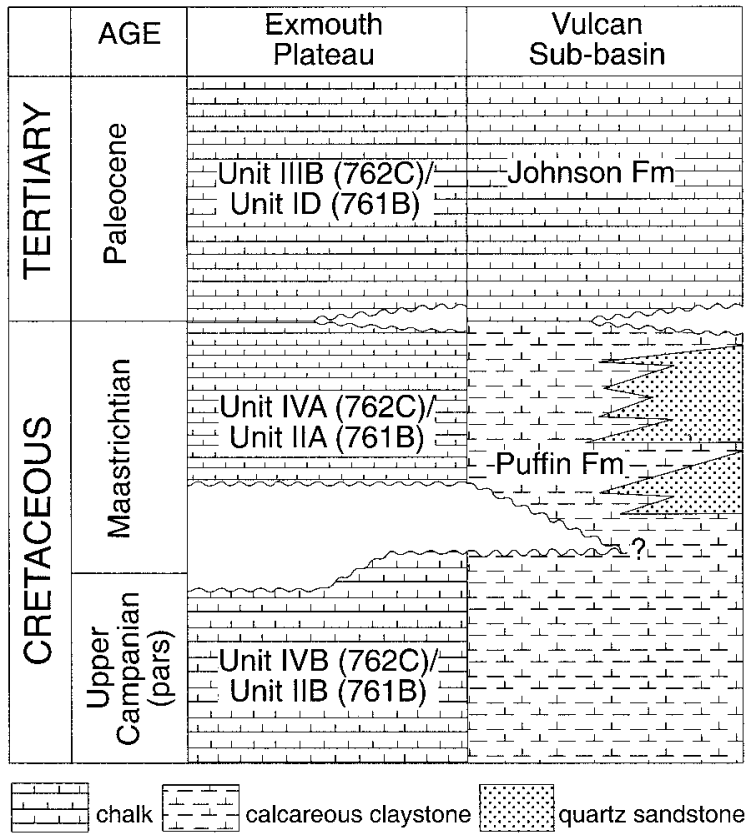

Fig. 5. Lithostratigraphy of the Exmouth Plateau and Vulcan Sub-basin (modified after Exon et al., 1992b and Pattillo \& Nicholls, 1990). 


\begin{tabular}{|l|c|l|l|l|l|}
\hline Well & $\begin{array}{l}\text { Thickness of } \\
\text { Maastrichtian } \\
\text { Sediments }\end{array}$ & Basin & Latitude ${ }^{\circ} \cdots$ ') & Longitude ${ }^{\circ} \cdots$ ' $)$ & \multicolumn{1}{|c|}{ Operator } \\
\hline Delta 1 & $\sim 127 \mathrm{~m}$ & Browse Basin & 123856.4 & 1235813.1 & Elf Aquitaine \\
Langhorne 1 & $\sim 110.5 \mathrm{~m}$ & Browse Basin & 115846.0 & 1242156.0 & TCPL Resources Ltd \\
ODP Hole 761B & $\sim 27 \mathrm{~m}$ & Exmouth Plareau & 164413.80 & 115326.00 & ODP \\
ODP Hole 762C & $\sim 47 \mathrm{~m}$ & Exmouth Plareau & 195313.80 & 1121514.40 & ODP \\
Birch 1 & $\sim 229 \mathrm{~m}$ & Vulcan Sub-basin & 122733.88 & 1242943.44 & BHP Petroleum Pty Ltd \\
Kimberley 1 & $\sim 443 \mathrm{~m}$ & Vulcan Sub-basin & 123610.5 & 1242259.11 & Norcen International Limited \\
Leeuwin 1 & $\sim 259 \mathrm{~m}$ & Vulcan Sub-basin & 124240.35 & 1243506.32 & BHP Petroleum Pty Ltd \\
Parry 1 & $\sim 195 \mathrm{~m}$ & Vulcan Sub-basin & 121614.33 & 1242015.06 & BHP Petroleum Pty Ltd \\
Rothbury 1 & $\sim 155 \mathrm{~m}$ & Vulcan Sub-basin & 120735.88 & 1242833.04 & TCPL Resources Ltd \\
Swan 3ST & $\sim 275 \mathrm{~m}$ & Vulcan Sub-basin & 121141.36 & 1242937.0 & BHP Petroleum Pty Ltd \\
\hline
\end{tabular}

Table 1. Wells examined in this study.

sections on the basis of the benthonic foraminiferal assemblages which include the species Aragonia velascoensis, Bulimina velascoensis, Cibicidoides spp., Gaudryina pyramidata, Nuttallides truempyi, Nuttallinella florealis, Pullenia spp., Reussella szajnochae, and Stensioeina beccariiformis, and high planktonic foraminiferal percentages, typically $>80 \%$.

Vulcan Sub-basin. Strata of Maastrichtian age in the central and southern Vulcan Sub-basin belong to the Puffin and Borde Formations (Fig. 5). These units reach a maximum thickness of $570 \mathrm{~m}$ in the Vulcan Sub-basin, and consist of expanded sections of turbiditic sandstones with interbedded calcareous claystones and marls (Mory, 1988; Pattillo \& Nicholls, 1990). The sandstones represent massive channelized submarine fan complexes derived from the southeast (Pattillo \& Nicholls, 1990), and are proven petroleum reservoirs (e.g. Puffin 1 and East Swan 1). The benthonic foraminiferal assemblages generally contain diverse rotaliids, lagenids, buliminids and agglutinated taxa, including Bolivinoides spp., Cibicidoides spp, Eouvigerina subsculptura, Globorotalites conicus, Glomospira charoides, Gyroidinoides spp., Nuttallinella florealis, Osangularia cordieriana, Paralabamina spp., Praebulimina reussi, Pullenia spp., Reussella szajnochae and Stensioeina beccariiformis. These assemblages indicate bathyal depositional environments of more than $200 \mathrm{~m}$, which is supported by a predominance of planktonic foraminifera over benthonic foraminifera within the residues.

\section{MATERIALS AND METHODS}

This study is based on material from eight offshore petroleum wells in the Vulcan Sub-basin, and two Ocean Drilling Program (ODP) wells on the Exmouth Plateau (Table 1, Figures 3, 4). The ODP wells were selected because they are continuously cored sections and recovered microfossil assemblages are generally well preserved. The wells from the Vulcan Sub-basin were selected because of expanded Maastrichtian sections and adequate side-wall core spacing. Side-wall core samples were examined from the Vulcan Sub-basin wells at a typical spacing of 10-30 m. Core samples were collected from ODP 761B and ODP $762 \mathrm{C}$ at a typical spacing of $1-5 \mathrm{~m}$. The ODP samples were processed for foraminifera using standard preparation techniques (see Glaessner, 1948). These include boiling and disaggregation of samples in a solution of water, calgon and detergent, and then passing the resulting slurry through a $75 \mu \mathrm{m}$ mesh sieve. The $>75 \mu \mathrm{m}$ sand fractions were then collected on filter paper in a Buchner funnel, dried and stored in plastic vials. For calcareous nannofossils, smear slides were prepared using the techniques outlined in Perch-Nielsen (1985) and Bown \& Young (1998). A small amount of fresh rock was scraped onto a coverslip and then smeared evenly with a wet toothpick. The coverslip was then dried on a hotplate before being glued to a glass slide using Norland optical adhesive.

The Vulcan Sub-basin side-wall core samples had been processed prior to this study by International Stratigraphic Consultants Pty Ltd. All sand-fractions were selectively picked for planktonic foraminifera and biostratigraphically important benthonic foraminifera, and representative specimens were mounted on slides. Nannofossil slides were examined at $1250 \times$ magnification using a Zeiss Photomicroscope III cross-polarizing microscope, and taxa were recorded semi-quantitatively. Wellpreserved foraminiferal specimens were digitally imaged under the Phillips 505 Scanning Electron Microscope (SEM), having been sputter-coated for 8 minutes with gold at 20-30 mA. Digital images of the nannofossils were captured using a Blue and White Power Macintosh G3/450 and Polaroid DMC 2 digital camera mounted onto the light microscope. All images were imported into Extensis Portfolio 5, a cross-platform image-cataloguing program and are available at http:// www.geol.uwa.edu.au/ biostrat/, and on CD from the authors. All of the samples and slides used in this study are kept in the calcareous nannofossil and foraminiferal collections in the School of Earth \& Geographical Sciences at the University of Western Australia.

\section{RESULTS}

Four zonations are outlined below (Fig. 6), the $\mathrm{KCN}$ calcareous nannofossil zonation, with seven zones and seven subzones, the KPF planktonic foraminiferal zonation with six zones and five subzones, the $\mathrm{KBF}$ benthonic foraminiferal zonation with one zone, and the KCCM composite calcareous microfossil zonation, with eight zones and 11 subzones, which combines the $\mathrm{KCN}, \mathrm{KPF}$, and $\mathrm{KBF}$ zonations to achieve a robust, high resolution zonation. All of these zonations are modified 


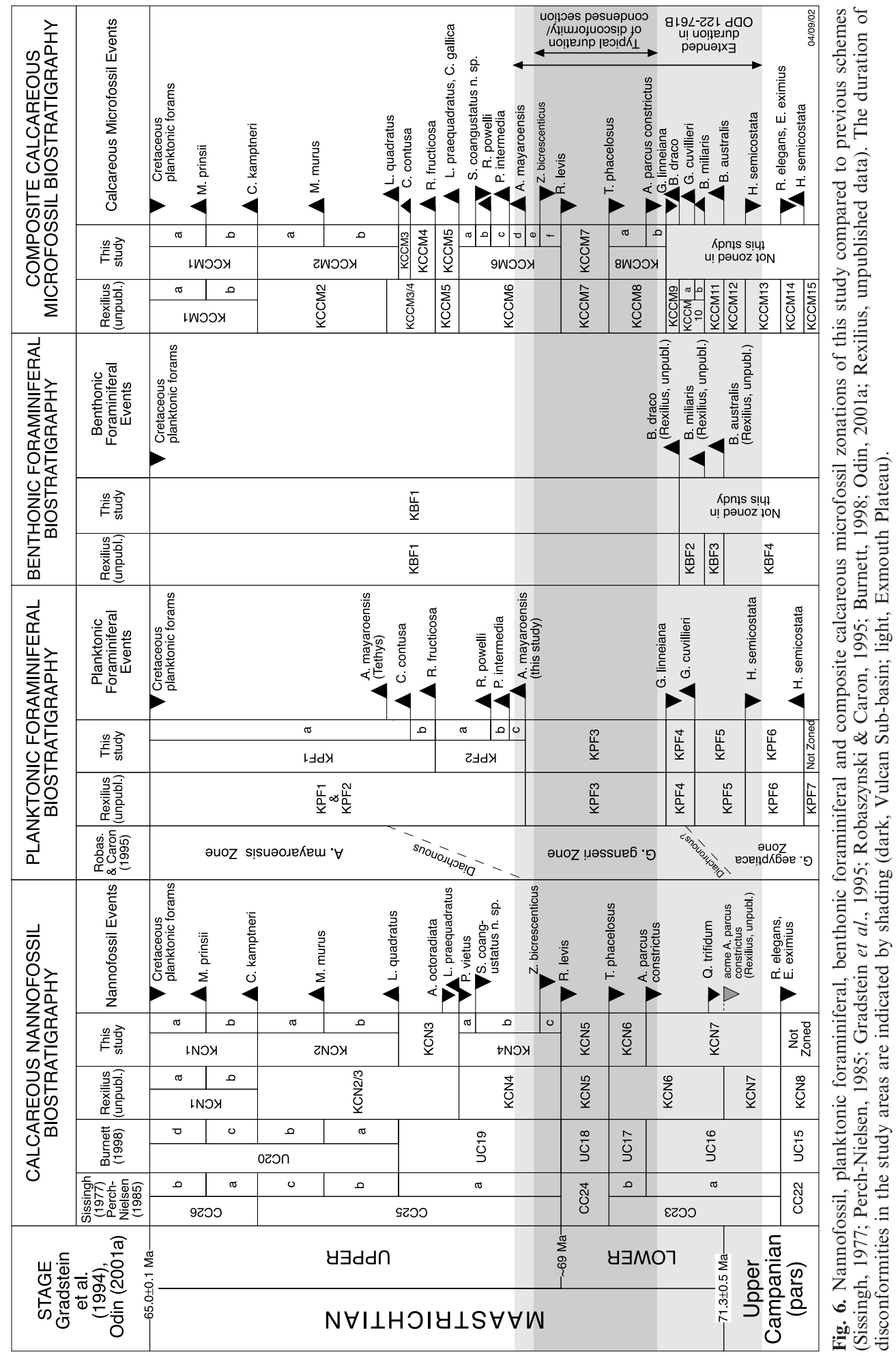


R. W. Howe et al.

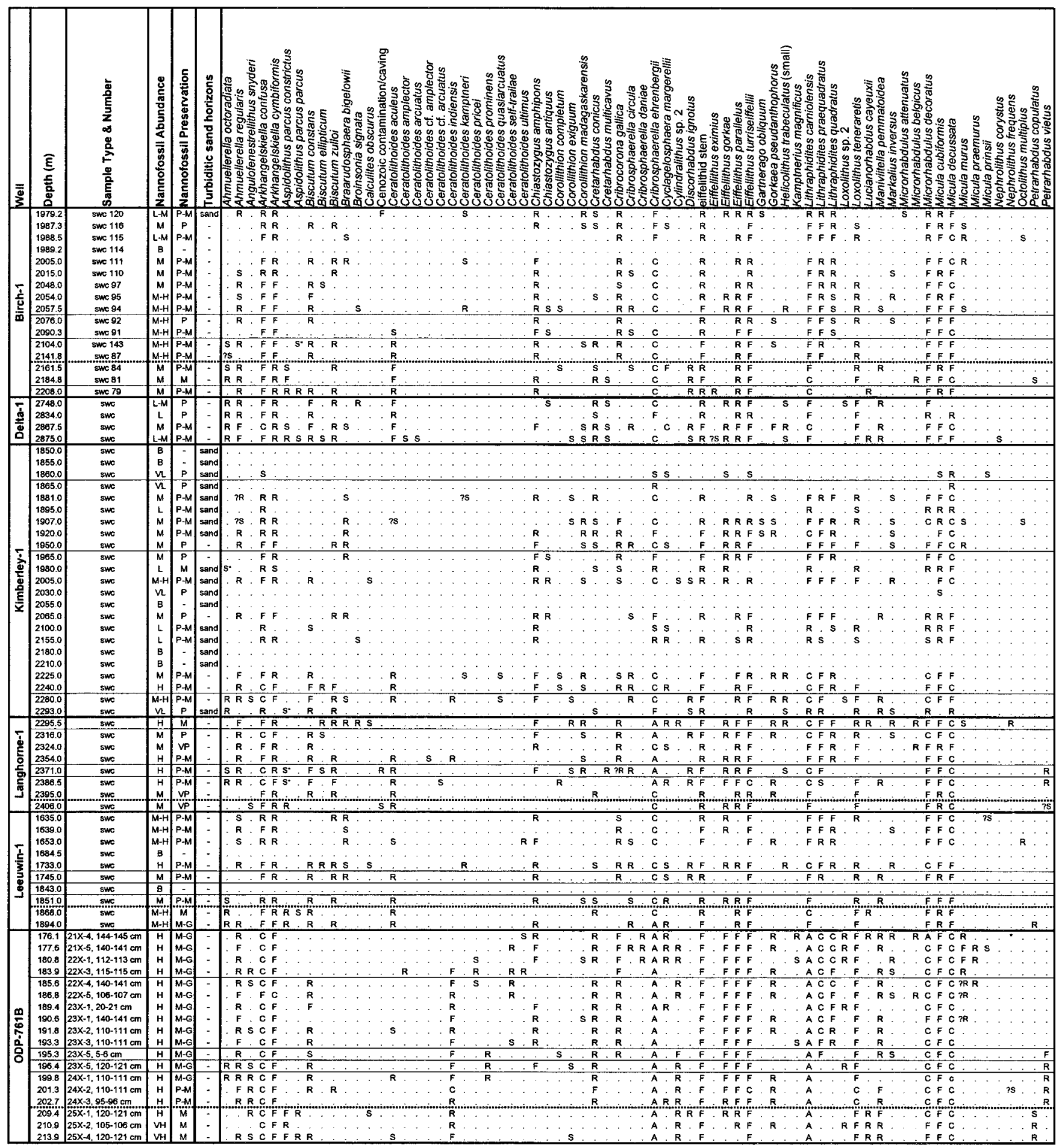

Table 2. Dashed line indicates interpreted position of the Upper Campanian to upper Lower Maastrichtian disconformity (not present in some wells). Abundance is recorded as: VH, very high, $>100$ specimens per field of view (FOV); H, high, 50-100 specimens per FOV; M, moderate 10-50 specimens per FOV; L, low, 1-10 specimens per FOV; VL, very low, 1 specimen per 1-10 FOVs. Individual species abundances are recorded as follows: A, abundant, $>100$ specimens per FOV; C, common, 11-100 specimens per FOV; F, few, 1-10 specimens per FOV; R, rare, 1 specimen in 10 FOVs; S, single, only a single specimen observed. As the nannofossil assemblage in a sample can show overgrowth of some species, and dissolution of others, only the overall preservation state of the assemblage is recorded here as: G, good, whole assemblage is well preserved, with the diagnostic features of most species preserved; M, moderate, with some dissolution and/or overgrowth, but most species still identifiable, $\mathrm{P}$, poor, severe dissolution and/or overgrowth, with only a few species identifiable to species level. 


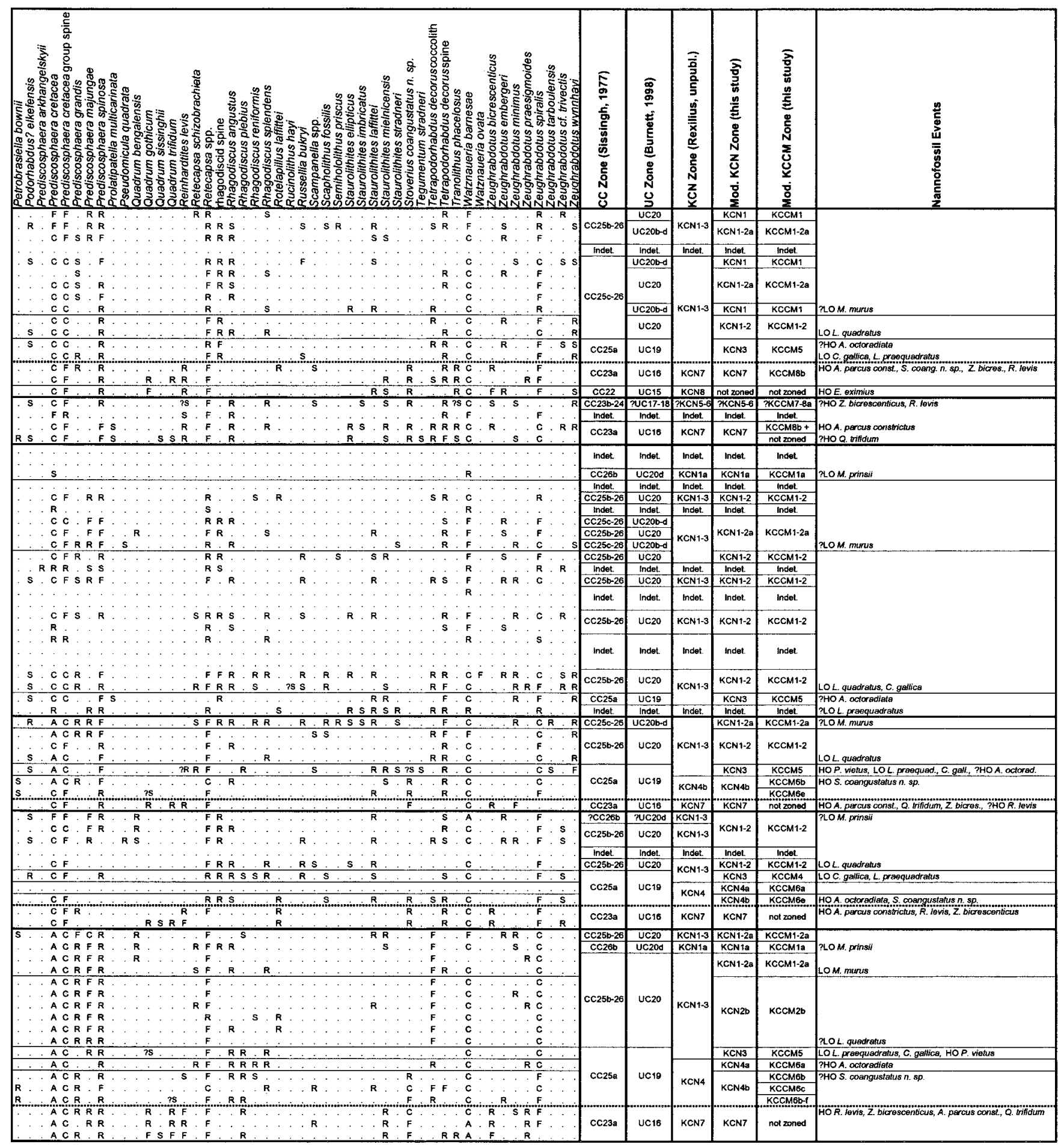

Table 2. Continued.

refinements of the unpublished $\mathrm{KCN}, \mathrm{KPF}, \mathrm{KBF}$ and KCCM zonations (see Fig. 5) used by J.P. Rexilius in petroleum exploration work. The KBF benthonic foraminiferal zonation is based on evolutionary lineages within the genus Bolivinoides and is best developed in neritic facies. The lineage is poorly represented in our bathyal material because of unfavourable facies and, therefore, the $\mathrm{KBF}$ zonation was difficult to apply. Comparisons to the CC nannofossil zones of Sissingh (1977) and Perch-Nielsen (1985), the UC nannofossil zones of Burnett (1998), the C planktonic foraminiferal zones of Wright \& Apthorpe (1976, 1995), and the revised $\mathrm{KCN}, \mathrm{KPF}$ and $\mathrm{KCCM}$ zones are shown on 


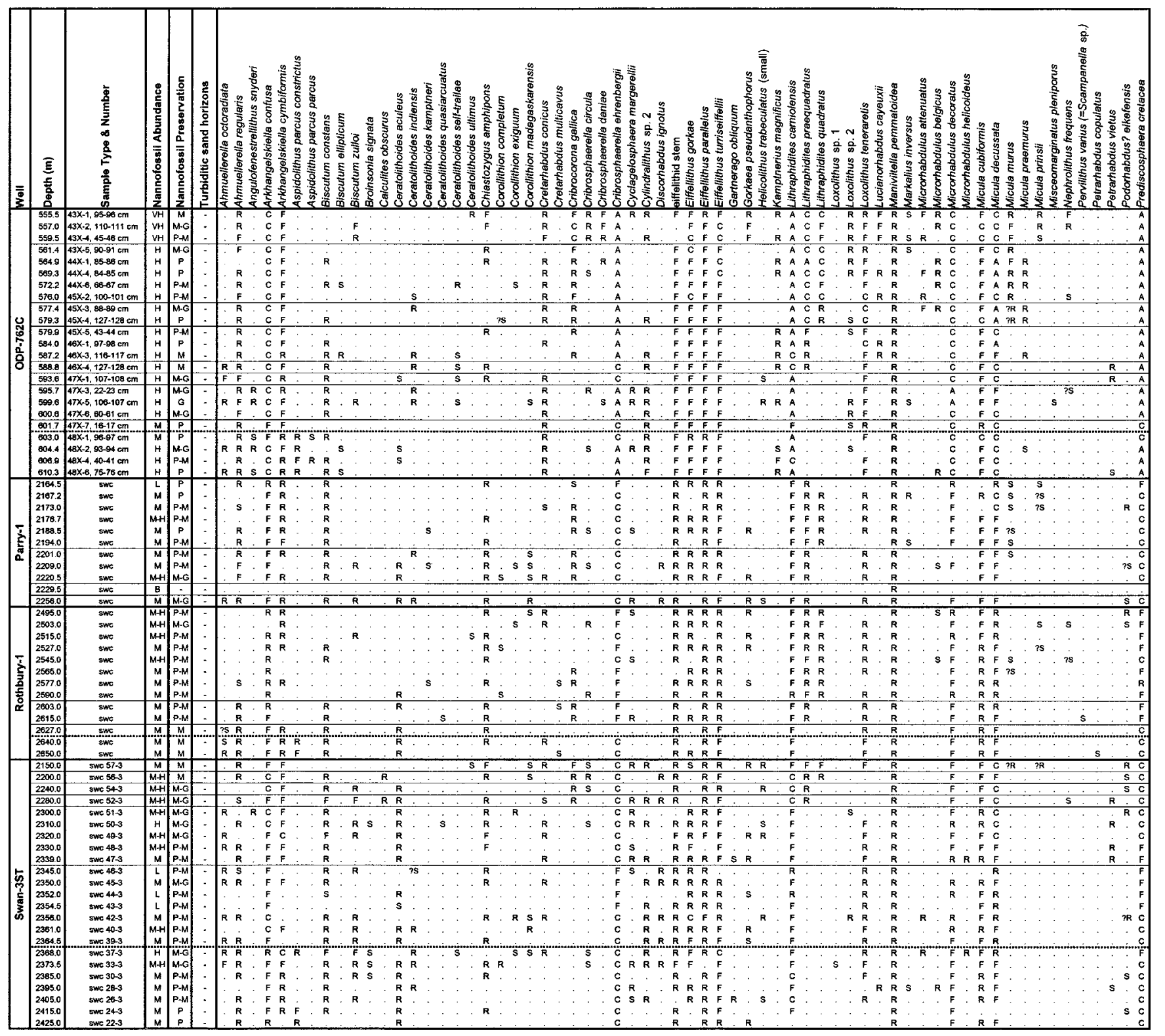

Table 2. Continued.

the nannofossil and foraminiferal distribution charts (Tables 2, 3).

Stratigraphic correlation of the KCCM Zonation to the European Campanian and Maastrichtian Stages is mainly based on calcareous nannofossil events. The planktonic foraminiferal assemblages of northwestern Australia are significantly different to those in Europe and the Mediterranean region, since a number of the key markers used in these regions (see Premoli Silva \& Sliter, 1994; Robaszynski \& Caron, 1995; Odin et al. 2001) are either absent or have different ranges in Australia (e.g. Radotruncana calcarata). Broad correlations can be made using benthonic foraminiferal events, although the distribution of benthonic species tends to be more facies driven than the distribution of planktonic species.
The Maastrichtian/Campanian boundary GSSP (Global Stratotype Section and Point) was recently ratified by the International Commission on Stratigraphy (ICS) and is located in a disused quarry at Tercis-les-Bains in southwest France (Odin, 2001a). The marker events that define the boundary are the lowest occurrences (LOs) of the Tethyan ammonite Pachydiscus neubergicus and the Boreal belemnite Belemnella lanceolata (Odin \& Lamaurelle, 2001). These events have been correlated to the base of the Baculites eliasi ammonite zone in the US Western Interior (Kennedy et al., 1992; Gradstein et al., 1994; Hardenbol \& Robaszynski, 1998). The numerical age given for this level by Gradstein et al. (1994) is $71.3 \pm 0.5 \mathrm{Ma}$, which is followed in this study, although a numerical age of $72.0 \mathrm{Ma}$ was calibrated for the boundary at Tercis (Odin, 2001b). 


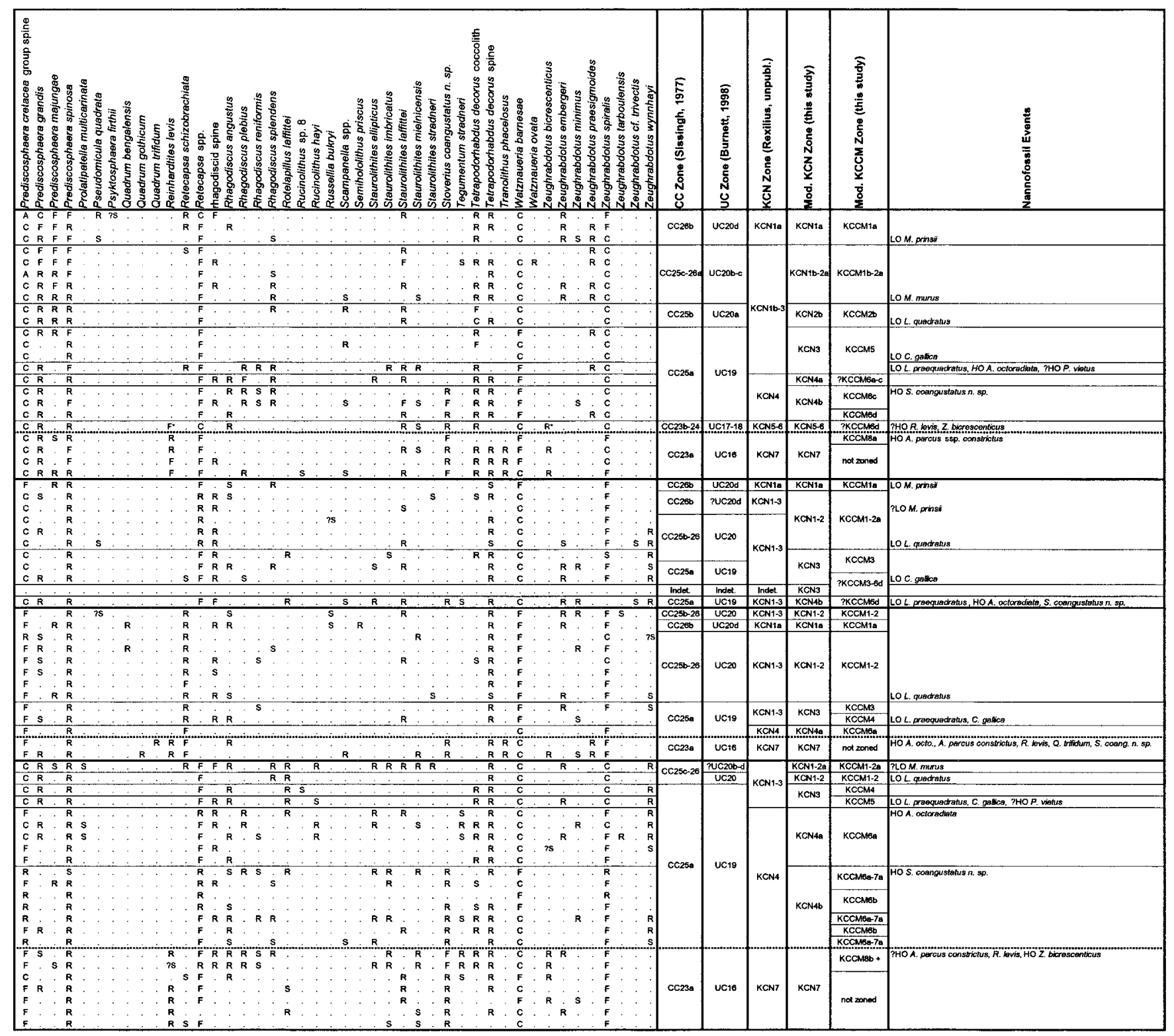

Table 2. Continued.

At Tercis, calcareous nannofossil, planktonic foraminiferal, and benthonic foraminiferal events have been tied to the LO of Pachydiscus neubergicus. Studies by von Salis (2001), Gardin \& Monechi (2001) and Melinte \& Odin (2001) show that the HO (highest occurrence) of the nannofossil Aspidolithus parcus constrictus occurs significantly above the Maastrichtian/Campanian boundary, in contrast to earlier correlations that placed the event slightly below the boundary (Burnett et al., 1992a; Burnett, 1998). The HO of Quadrum trifidum is located above the boundary, below the HO of $A$. p. constrictus, while the HOs of Eiffelithus eximius and Reinhardtites anthophorus were shown to be slightly below the boundary (Gardin et al., 2001).

The LO of $P$. neubergicus has been shown to occur well above the HO of the planktonic foraminiferal marker Radotruncana calcarata (Premoli Silva \& Sliter, 1994; Robaszynski \& Caron,
1995; Ion \& Odin, 2001) and correlated to within the Gansserina gansseri Zone (Robaszynski et al., 1984; Premoli Silva \& Sliter, 1994). It is interesting that at Tercis the LO of G. gansseri occurs above the Maastrichtian-Campanian boundary (Odin et al., 2001), suggesting that the appearance of this species may be diachronous. In terms of benthonic foraminifera, Bolivinoides $\mathrm{cf}$. australis was recorded above the Maastrichtian-Campanian boundary at Tercis, while $B$. miliaris ranged from the uppermost Campanian to the lower Lower Maastrichtian (Tronchetti, 2001). Tronchetti et al. (2001) note a change at the CampanianMaastrichtian boundary from Bolivinoides taxa with four lobes on the suture of the final chambers to specimens with five lobes above the boundary. In this study we have correlated the LO of Bolivinoides australis to approximate the Campanian-Maastrichtian boundary, following Robaszynski 


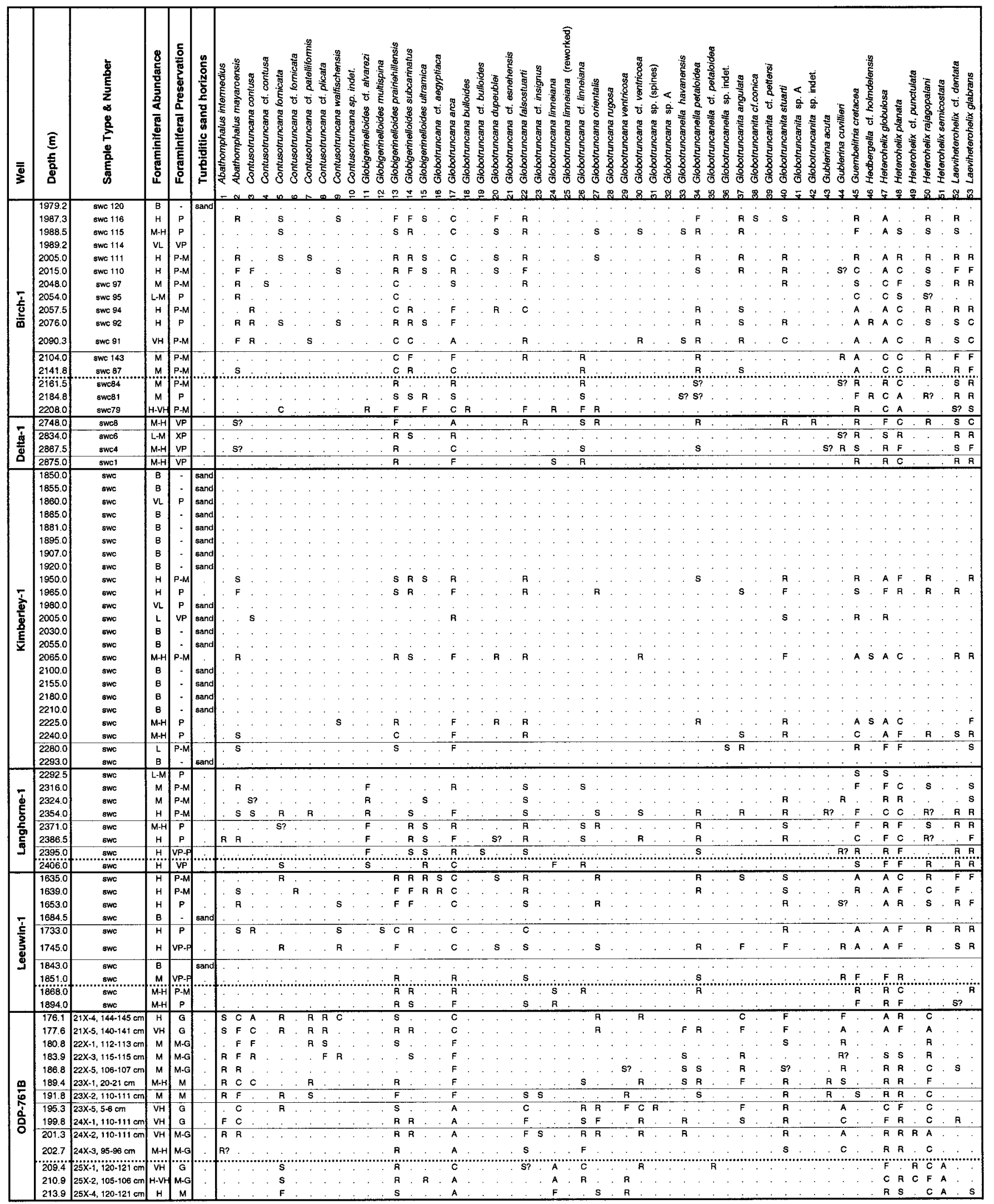

Table 3. Dashed line indicates interpreted position of the Upper Campanian to upper Lower Maastrichtian disconformity (not present in some wells). Abundance is recorded as: A, abundant ( $>50$ specimens per sample); C, common ( $20-50$ specimens per sample); F, frequent (10-19 specimens per sample); R, rare (2-9 specimens per sample); and S, single (1 specimen per sample). Preservation is recorded as: G, good; M, moderate; and $\mathrm{P}$, poor, and was dependent on the level of recrystallization, overgrowth and/or dissolution. Asterisk denotes probably caved specimens 
Upper Cretaceous biostratigraphy, offshore NW Australia

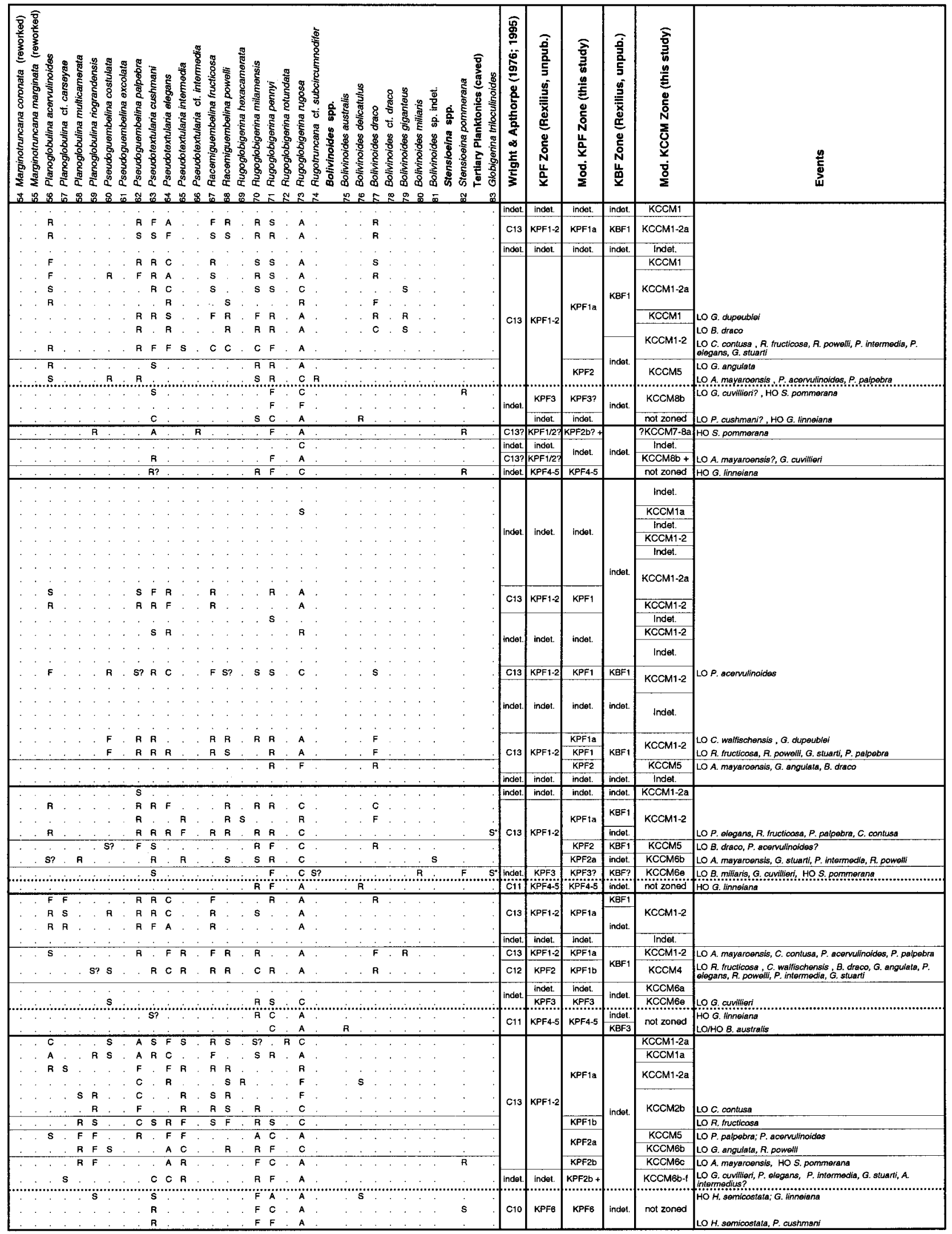

Table 3. Continued. 


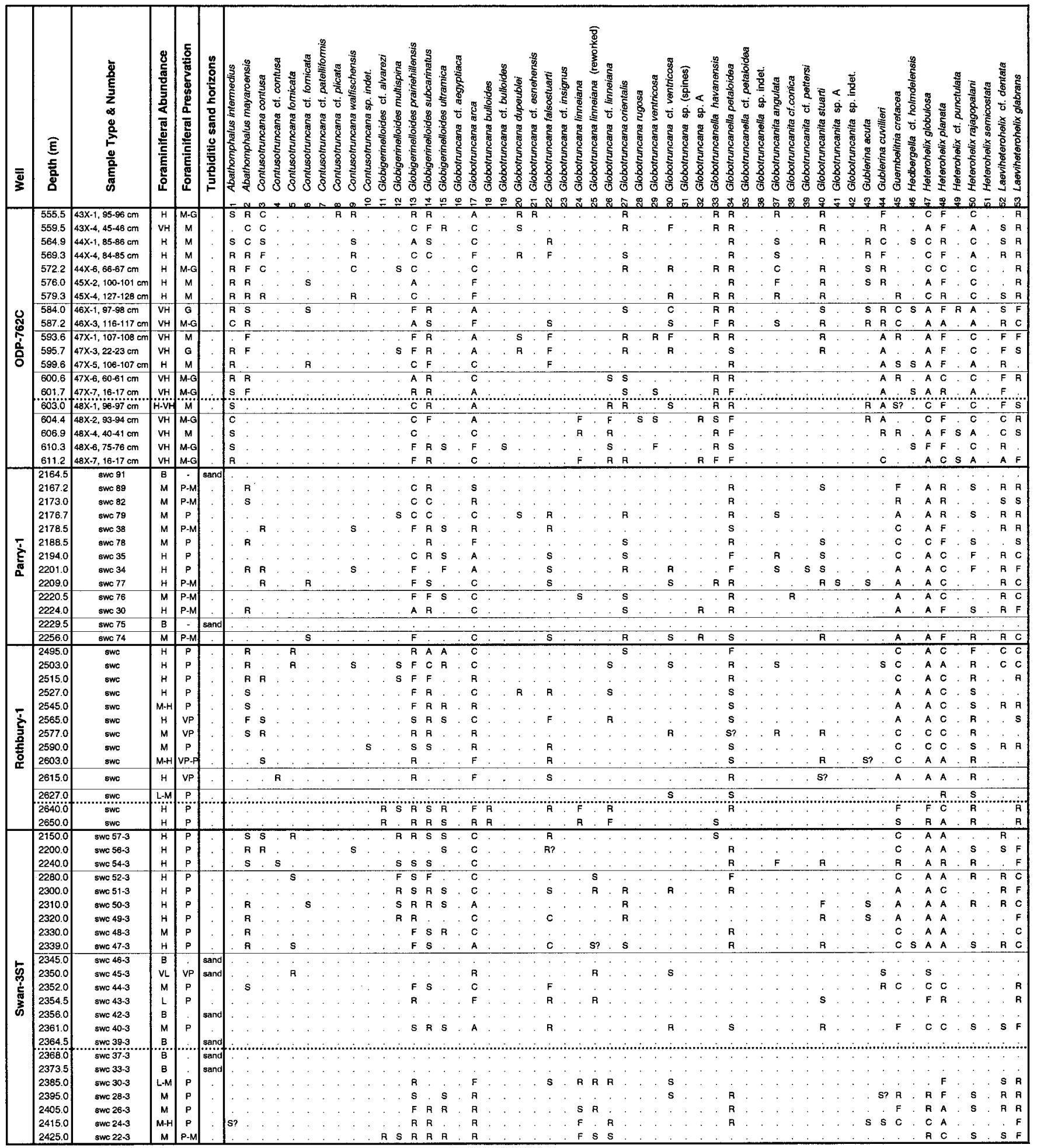

Table 3. Continued.

et al. (1984) and in agreement with the lobe observations of Tronchetti et al. (2001).

The subdivision of the Maastrichtian Stage into Upper and Lower substages is informal. The candidate GSSP for the substage boundary is the section at Zumaya, northern Spain (Odin, 1996). Potential markers for the substage boundary include the $\mathrm{HO}$ of rudistid reefs, the $\mathrm{HO}$ of the majority of inoceramids, and the LO of the ammonite 
Upper Cretaceous biostratigraphy, offshore NW Australia

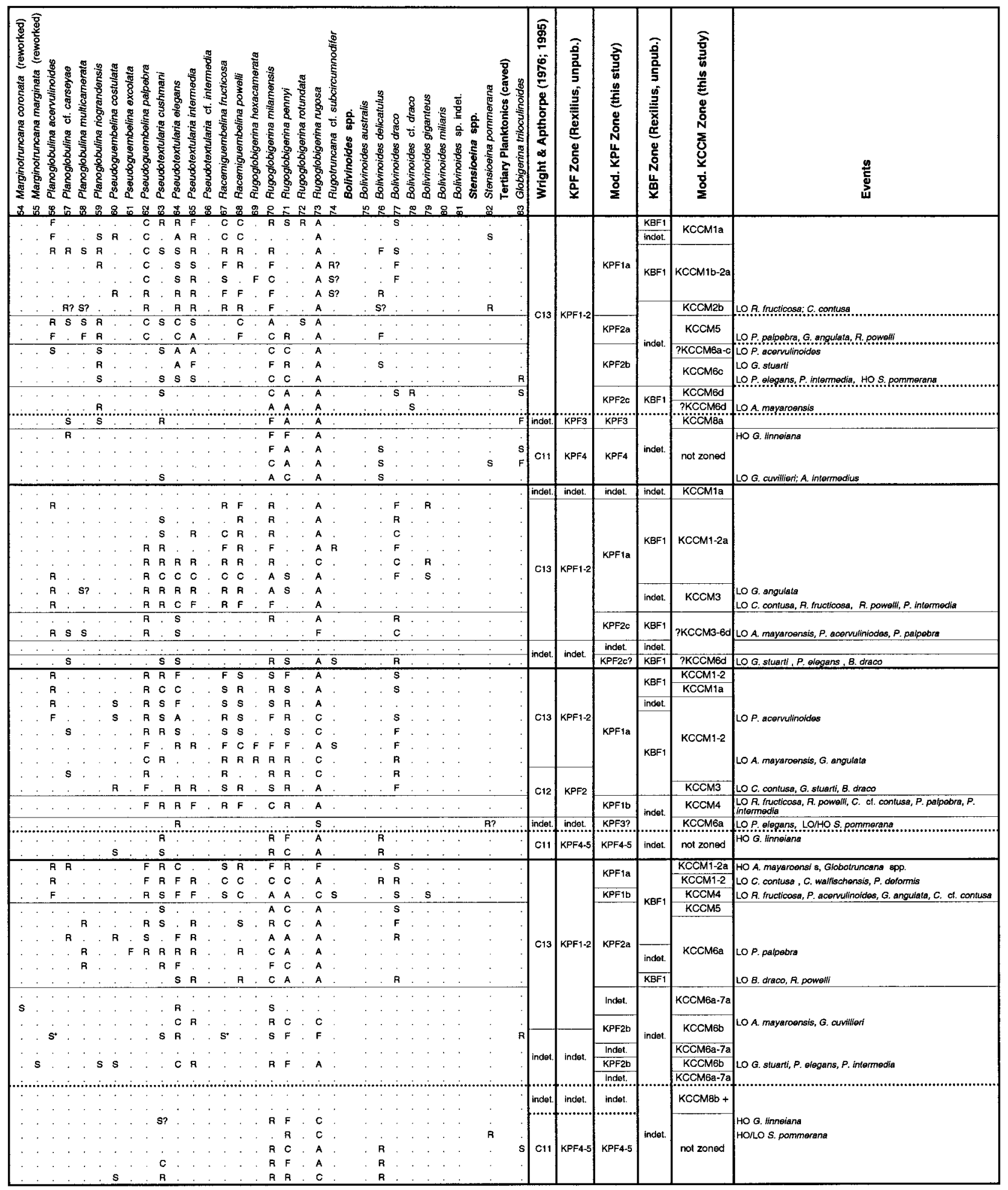

Table 3. Continued.

Pachydiscus fresvillensis (Odin, 1996). Another possible marker is the LO of the ammonite Pachydiscus gollevillensis which was used by Gradstein et al. (1994) and is correlated to about 69 Ma. MacLeod (1994a) notes that the HO of inoceramids in the Zumaya Formation occurs within the upper Gansserina gansseri
Zone-lower Abathomphalus mayaroensis Zone (planktonic foraminifera), within Zones CC24-25a (nannofossils), within the $P$. fresvillensis Zone (ammonite) and within magnetochron $31 \mathrm{~N}$. Correlation of the ammonite data from the Zumaya section (Ward \& Kennedy, 1993) with the inoceramid (MacLeod, 
1994a) and nannofossil data (Burnett et al., 1992b) indicates that the LO of $P$. gollevillensis occurs just below the $\mathrm{HO}$ of the inoceramids, within Zones CC24-25a, and in the upper Gansserina gansseri Zone. In contrast, the LO of $P$. fresvillensis occurs a lot lower in the succession, within the G. gansseri Zone and in upper CC23B (Ward \& Kennedy, 1993; MacLeod, 1994a).

\section{Calcareous nannofossil biostratigraphy}

All taxa referred to in this section are illustrated in Plates $1-4$.

\section{Zone KCN1}

Definition. Interval from the $\mathrm{HO}$ of Cretaceous planktonic foraminifera to the LO of Ceratolithoides kamptneri. Upper Cretaceous nannofossils are abundantly reworked into lower Danian sediments on the northwestern Australian margin (JPR, unpublished data), so the HO of Cretaceous nannofossils is not a useful event for marking the top of the Maastrichtian. The HO of Cretaceous planktonic foraminifera, which are much less easily reworked, is a preferred event and is used in this study.

Age. Late Late Maastrichtian.

Remarks. In this study, C. kamptneri is rare and sporadic in occurrence.

\section{Subzone KCN1a}

Definition. Interval from the $\mathrm{HO}$ of Cretaceous planktonic foraminifera to the LO of Micula prinsii.

Age. Latest Maastrichtian.

Remarks. In this study, $M$. prinsii is rare and sporadic in occurrence. Cribrosphaerella daniae and Nephrolithus frequens are sometimes present in association with $M$. prinsii, particularly in ODP Holes 761B and 762C, and are used as proxies to indicate this subzone in the absence of $M$. prinsii.

\section{Subzone KCN1b}

Definition. Interval from the LO of Micula prinsii to the LO of Ceratolithoides kamptneri.

Age. Late Late Maastrichtian.

\section{Zone KCN2}

Definition. Interval from the LO of Ceratolithoides kamptneri to the LO of Lithraphidites quadratus s. s.

Age. Middle Late Maastrichtian.

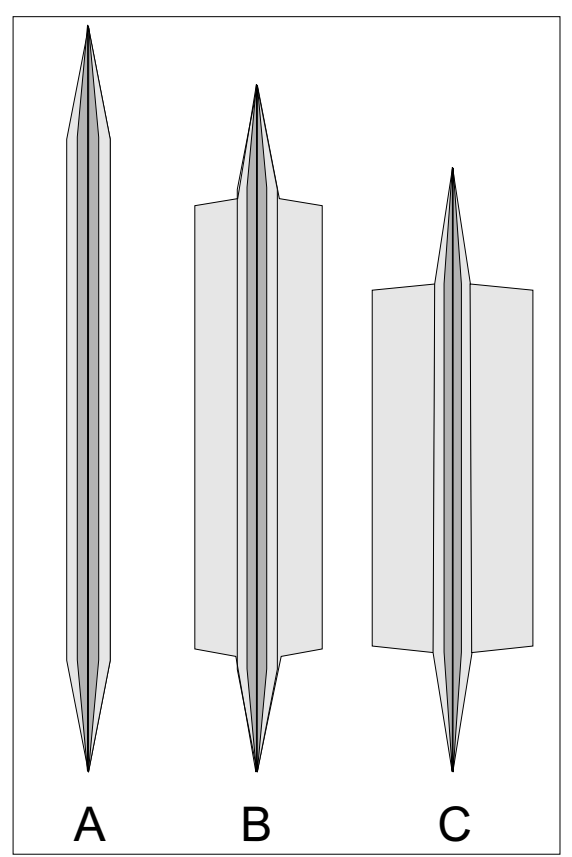

Fig. 7. Morphological criteria of Roth (1978) for the separation of (A) Lithraphidites carniolensis (Length/Width ratio $\geqq 5$ ), (B) L. praequadratus $(3.5<$ Length/Width ratio $<5$ ), and (C) L. quadratus (Length/Width ratio $\leq 3.5)$.

Remarks. In this study, Lithraphidites quadratus and L. praequadratus have been separated morphometrically following the criteria of Roth (1978); Figure 7.

\section{Subzone KCN2a}

Definition. Interval from the LO of Ceratolithoides kamptneri to the LO of Micula murus.

Age. Middle Late Maastrichtian.

Remarks. In this study, $M$. murus is rare and sporadic in occurrence.

\section{Subzone KCN2b}

Definition. Interval from the LO of Micula murus to the LO of Lithraphidites quadratus s. $s$.

Age. Middle Late Maastrichtian.

\section{Zone KCN3}

Definition. Interval from the LO of Lithraphidites quadratus s. $s$. to the LO of L. praequadratus s. $s$. and Cribrocorona gallica.

Age. Middle Late Maastrichtian.

Remarks. The HO of Petrarhabdus vietus occurs at about the same level as the LO of $L$. praequadratus and $C$. gallica. The $\mathrm{HO}$ of Ahmuellerella octoradiata is within $\mathrm{KCN} 3$. C. gallica 

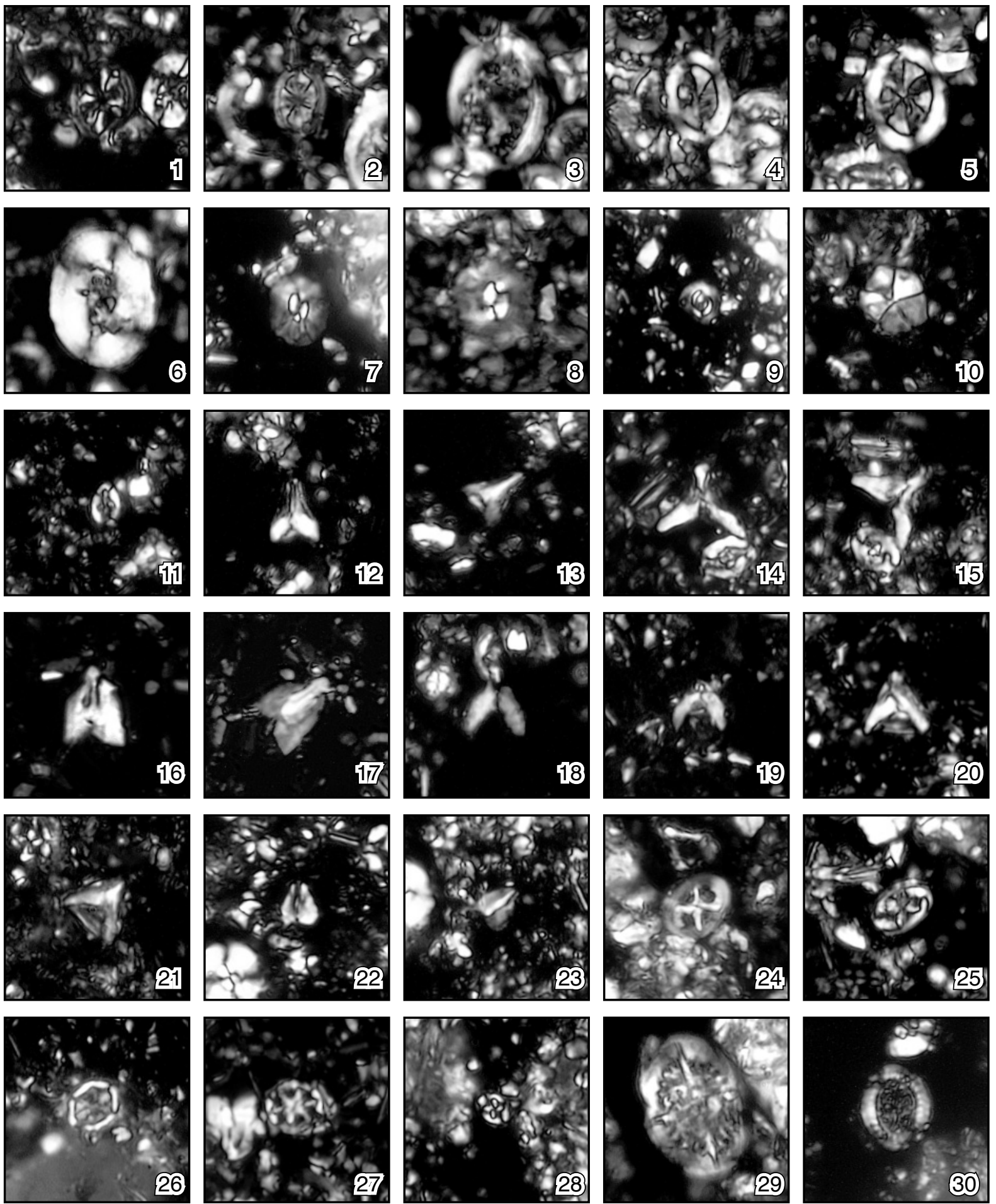

Explanation of Plate 1. All figures taken with cross-polarized light. Scale bar equal to $10 \mu \mathrm{m}$ on all figures. fig. 1. Ahmuellerella octoradiata, ODP 122-761B-23X-5, $120 \mathrm{~cm}$. fig. 2. Ahmuellerella regularis, ODP 122-762C-47X-3, $22 \mathrm{~cm}$. fig. 3. Angulofenestrellithus snyderi, ODP 122-761B-24X-1, $110 \mathrm{~cm}$. fig. 4. Arkhangelskiella confusa, ODP 122-761B-24X-2, $110 \mathrm{~cm}$. fig. 5. Arkhangelskiella cymbiformis, ODP 122-762C-43X-1, 95 cm. fig. 6. Aspidolithus parcus constrictus, ODP 122-761B-25X-1 $120 \mathrm{~cm}$. fig. 7. Biscutum constans, Swan ST3, 2240m. fig. 8. Biscutum ellipticum, ODP 122-762C-46X-3, $116 \mathrm{~cm}$. fig. 9. Biscutum zulloi, Swan ST3, 2385 m. fig. 10. Braarudosphaera bigelowii, Kimberley 1, $2280 \mathrm{~m}$. fig. 11. Broinsonia signata, Swan ST3, 2385m. figs 12-13. Ceratolithoides aculeus, Swan ST3, 2310 m. figs 14-15. Ceratolithoides arcuatus, Langhorne 1, 2386.5 m. figs 16-17. Ceratolithoides indiensis, ODP 122-761B-24X-1, $110 \mathrm{~cm}$. fig. 18. Ceratolithoides kamptneri, Parry 1, 2209 m. fig. 19. Ceratolithoides kamptneri, Birch 1, 2057.5 m. figs 20-21. Ceratolithoides quasiarcuatus, Swan ST3, $2310 \mathrm{~m}$. figs 22-23. Ceratolithoides ultimus, Swan ST3, $2150 \mathrm{~m}$. fig. 24. Chiastozygus amphipons, Langhorne 1, $2292.5 \mathrm{~m}$. fig. 25. Chiastozygus antiquus, Kimberley 1, 2225m. fig. 26. Corollithion completum, Birch 1, 2057.5 m. fig. 27. Corollithion exiguum, ODP 122-761B-25X-4, $121 \mathrm{~cm}$. fig. 28. Corollithion madagaskarensis, Kimberley 1, $2225 \mathrm{~m}$. fig. 29. Cretarhabdus conicus, Langhorne 1, 2386.5 m. fig. 30. Cretarhabdus multicavus, Swan ST3, $2310 \mathrm{~m}$. 

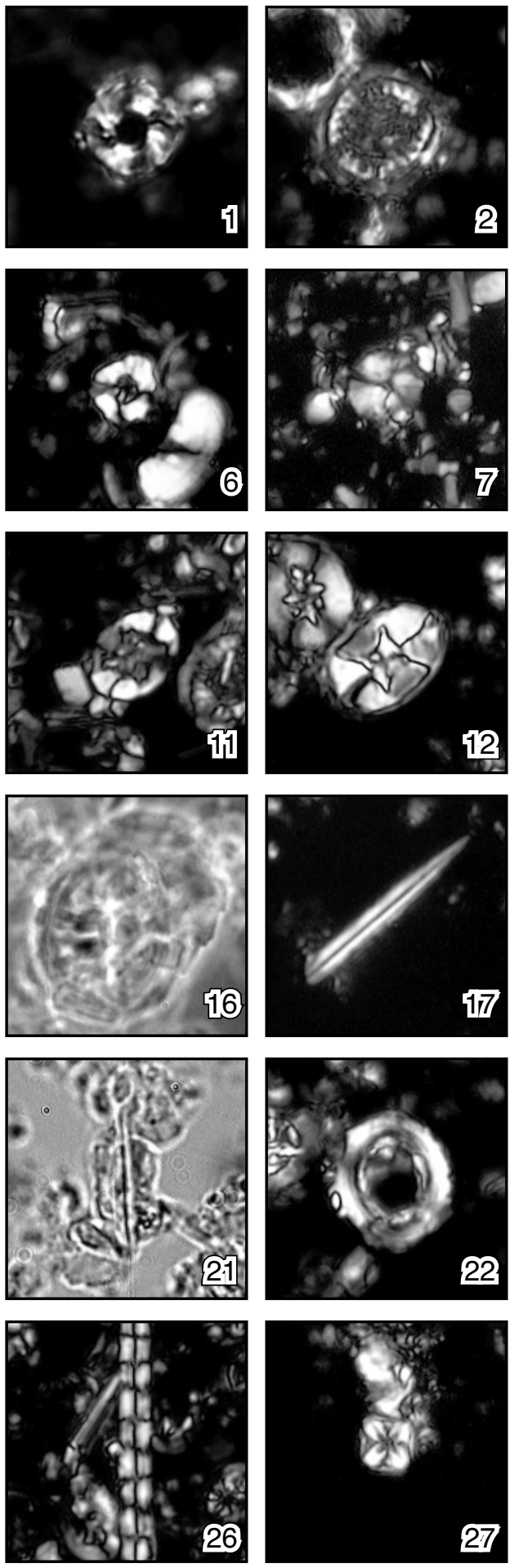
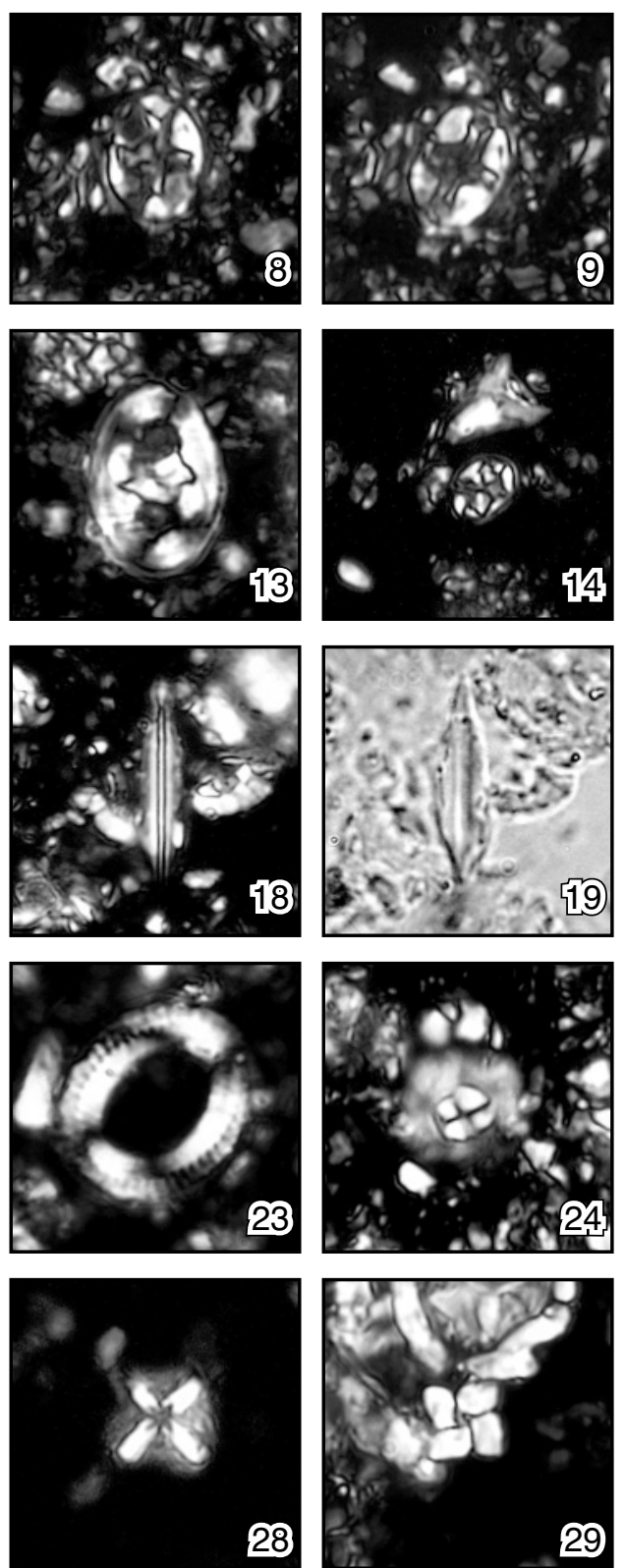
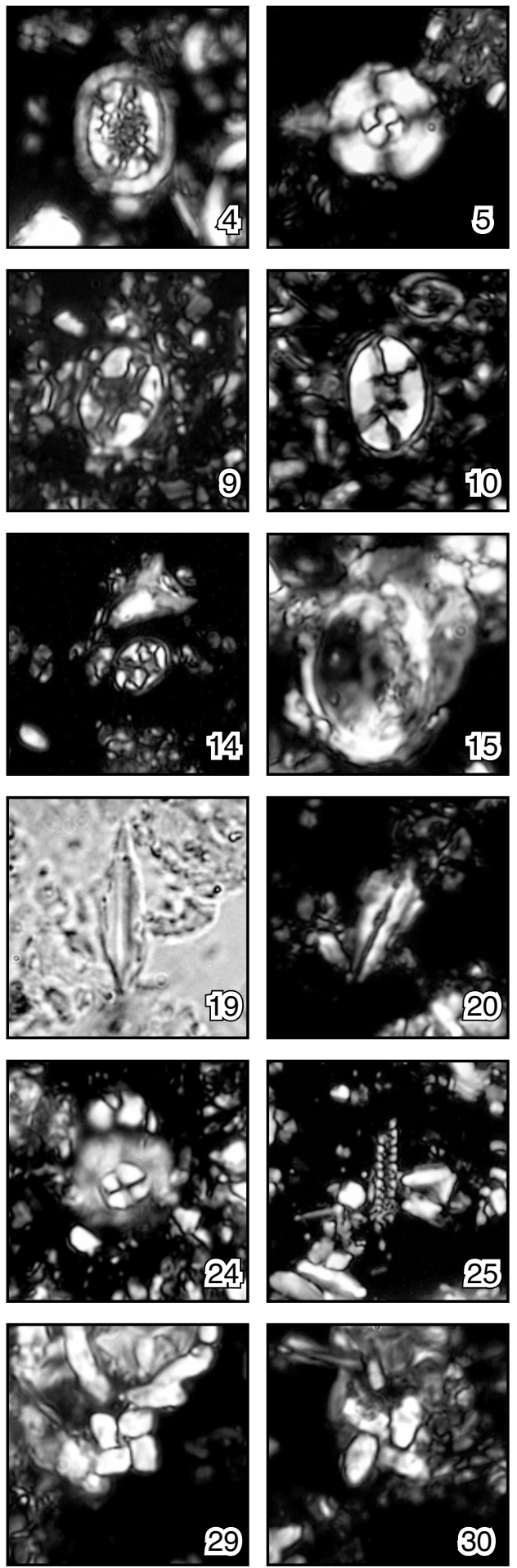

Explanation of Plate 2. All figures taken with cross-polarized light, except figs 16, 19, 21, which were taken with plain light. Scale bar equal to $10 \mu \mathrm{m}$ on all figures. fig. 1. Cribrocorona gallica, ODP 122-762C-43X-1, $96 \mathrm{~cm}$. fig. 2. Cribrosphaerella circula, Kimberley 1, $2280 \mathrm{~m}$. fig. 3. Cribrosphaerella daniae, ODP 122-762C-43X-1, 96 cm. fig. 4. Cribrosphaerella ehrenbergii, ODP 122-761B-24X-2, $110 \mathrm{~cm}$. fig. 5. Cyclagelosphaera reinhardtii, Swan ST3, $2310 \mathrm{~m}$. fig. 6. Cylindralithussp. 2, ODP 122-761B-25X-1, $120 \mathrm{~cm}$. fig. 7. Discorhabdus ignotus, ODP 761B-25X-1, $120 \mathrm{~cm}$. figs 8-9. Eiffellithus eximius, Birch 1, $2208 \mathrm{~m}$. fig. 10. Eiffellithus gorkae, ODP $761 \mathrm{~B}-24 \mathrm{X}-2,110 \mathrm{~cm}$. fig. 11. Eiffellithus parallelus, ODP $762 \mathrm{C}-43 \mathrm{X}-1,95 \mathrm{~cm}$. fig. 12. Eiffellithus turriseiffellii, OODP 122-23X-5, $120 \mathrm{~cm}$. fig. 13. Gorkaea pseudanthophorus, Langhorne 1, $2292.5 \mathrm{~m}$. fig. 14. Helicolithus trabeculatus (small), Swan ST3, $2240 \mathrm{~m}$. figs $15-16$. Kamptnerius magnificus, ODP 122-762C-46X-4, $127 \mathrm{~cm}$. fig. 17. Lithraphidites carniolensis, Delta 1, $2867.5 \mathrm{~m}$. figs 18-19. Lithraphidites praequadratus, Birch 1, 2057.5 m. figs 20-21. Lithraphidites quadratus, Swan ST3, 2200 m. fig. 22. Loxolithus teneraretis, ODP 122-762C-43X-1, 95 cm. fig. 23. Manivitella pemmatoidea, ODP 122-761B-24X-2, $110 \mathrm{~cm}$. fig. 24. Markalius inversus, Parry 1, $2194 \mathrm{~m}$. fig. 25. Microrhabdulus belgicus, ODP 122-761B, 25X-1, 120 cm. fig. 26. Microrhabdulus decoratus, ODP 761B-25X-1, $120 \mathrm{~cm}$. fig. 27. Micula cubiformis, Swan ST3, $2300 \mathrm{~m}$. fig. 28. Micula decussata, Birch 1, 2057.5 m. fig. 29. Micula murus, ODP 122-762C-43X-1, $95 \mathrm{~cm}$. fig. 30. Micula prinsii, ODP 122-762C-43X-1, $95 \mathrm{~cm}$. 

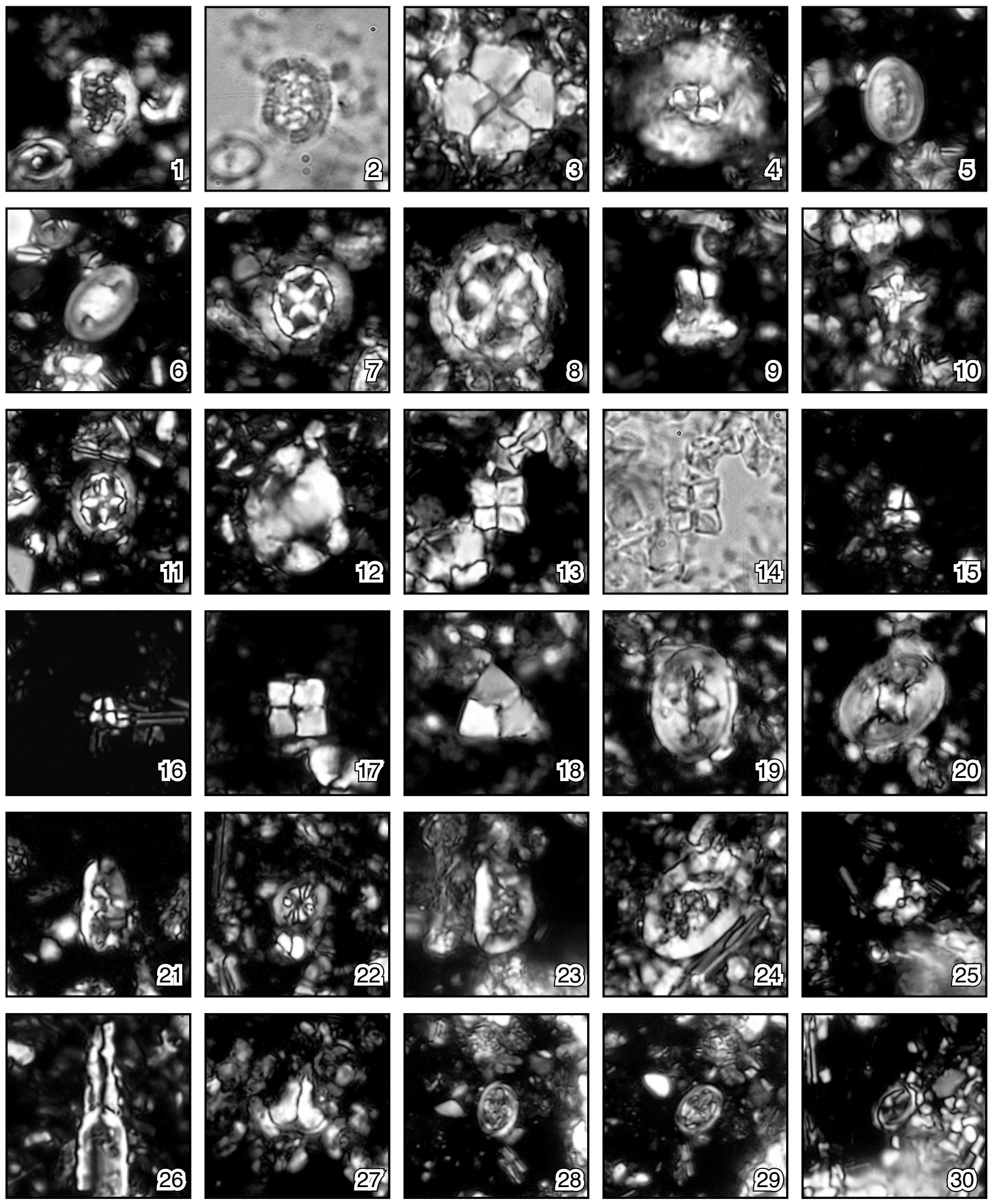

Explanation of Plate 3. All figures taken with cross-polarized light, except figs 2 and 14 which were taken with plain light. Scale bar equal to $10 \mu \mathrm{m}$ on all figures. figs 1-2. Nephrolithus frequens, ODP 762C-43X-1, $95 \mathrm{~cm}$. fig. 3. Petrarhabdus copulatus, ODP 761B-25X-4, 121 cm. fig. 4. Petrarhabdus vietus, Swan ST3, 2310 m. figs 5-6. Podorhabdus? elkefensis, Langhorne 1, $2292.5 \mathrm{~m}$. fig. 7. Prediscosphaera cretacea, ODP 762C-47X-1, 107 cm. fig. 8. Prediscosphaera grandis, Swan ST3, $2150 \mathrm{~m}$. fig. 9. Prediscosphaera majungae, ODP 761B-21X-4, $144 \mathrm{~cm}$. fig. 10. Prediscosphaera majungae, ODP 762C-43X-1, $95 \mathrm{~cm}$. fig. 11. Prediscosphaera spinosa, ODP 762C-47X-1, $107 \mathrm{~cm}$. fig. 12. Prolatipatella mutilcarinata, Swan ST3, $2150 \mathrm{~m}$. figs 13-14. Pseudomicula quadrata, ODP 762C-43X-4, $46 \mathrm{~cm}$. fig. 15. Quadrum bengalensis, Rothbury 1, $2503 \mathrm{~m}$. fig. 16. Quadrum bengalensis, ODP 761B-21X-4, $144 \mathrm{~cm}$. fig. 17. Quadrum gothicum, ODP 761B-25X-1, $120 \mathrm{~cm}$. fig. 18. Quadrum trifidum, ODP 761B-25X-1, $120 \mathrm{~cm}$. figs 19-20. Reinhardtites levis, ODP 761B-25X-1, $120 \mathrm{~cm}$. fig. 21. Rhagodiscus angustus, Delta 1, $2867.5 \mathrm{~m}$. fig. 22. Rhagodiscus plebius, ODP 762C-47X-1, $107 \mathrm{~cm}$. fig. 23. Rhagodiscus plebius, Delta 1, $2875 \mathrm{~m}$. fig. 24. Rhagodiscus splendens, ODP 761B-24X-2, $110 \mathrm{~cm}$. fig. 25. Russellia bukryi, Kimberley 1, $2225 \mathrm{~m}$. fig. 26. Scampanella sp., ODP 761B-24X-2, $110 \mathrm{~cm}$. fig. 27. Semihololithus priscus, Langhorne 1, $2292.5 \mathrm{~m}$. figs 28-29. Staurolithites ellipticus, Langhorne 1, $2292.5 \mathrm{~m}$. fig. 30. Staurolithites laffittei, ODP 762C-46X-4, $127 \mathrm{~cm}$. 

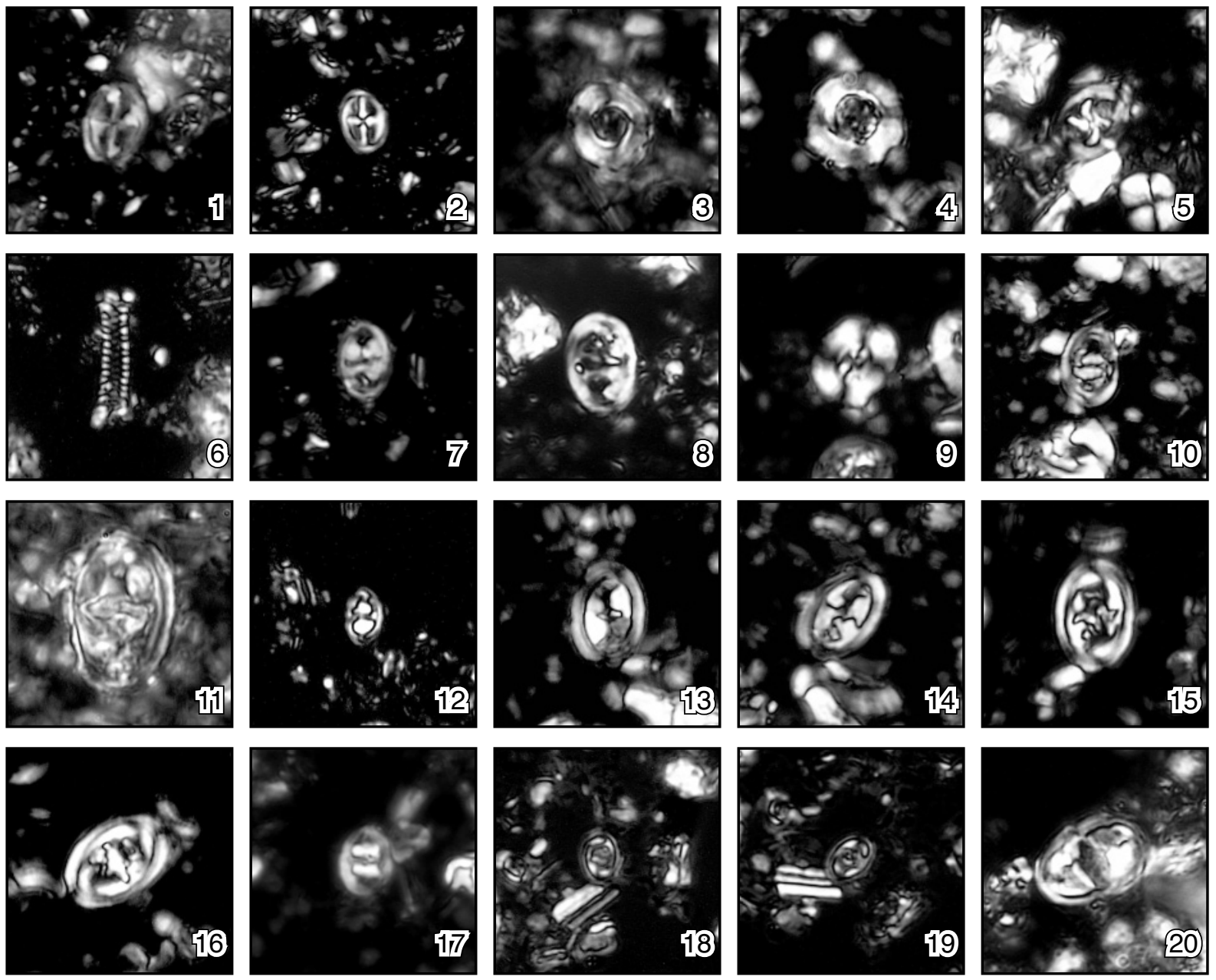

Explanation of Plate 4. All figures taken with cross-polarized light. Scale bar equal to $10 \mu \mathrm{m}$ on all figures. fig. 1. Staurolithites mielnicensis, Langhorne 1, 2354 m. fig. 2. Staurolithites stradneri, Swan 2150 m. fig. 3. Stoverius coangustatusn. sp., ODP 761B-24X-2, 110 cm. fig. 4. Stoverius coangustatus $\mathrm{n}$. sp., ODP 761B-25X-1, $120 \mathrm{~cm}$. fig. 5. Tegumentum stradneri, ODP 761B-25X-1, $120 \mathrm{~cm}$. fig. 6. Tetrapodorhabdus decorus spine, Swan ST3, 2240 m. fig. 7. Tranolithus phacelosus, Rothbury 1, 2640 m. fig. 8. Tranolithus phacelosus, Delta 1, $2875 \mathrm{~m}$. fig. 9. Watznaueria barnesae, ODP 762C-43X-1, $95 \mathrm{~cm}$. fig. 10. Zeughrabdotus bicrescenticus, ODP 761B-25X-1, $120 \mathrm{~cm}$. fig. 11. Zeughrabdotus embergeri, Rothbury 1, $2503 \mathrm{~m}$. fig. 12. Zeughrabdotus minimus n. comb., Swan ST3, 2300 m. figs 13-14. Zeugrhabdotus praesigmoides, ODP 761B-25X-1, $120 \mathrm{~cm}$. figs 15-16. Zeugrhabdotus spiralis, ODP 761B-25X-1, $120 \mathrm{~cm}$. fig. 17. Zeughrabdotus tarboulensis, Langhorne 1, 2292.5m. figs 18-19. Zeughrabdotus trivectis, Kimberley 1, 2240 m. fig. 20. Zeughrabdotus wynnhayi n. comb., Swan ST3, $2320 \mathrm{~m}$.

has been observed as ranging from the Late Campanian (?) to the Maastrichtian by Perch-Nielsen (1985), and Coniacian to Maastrichtian by Burnett (1998). Stoverius coangustatus n. sp. (the $\mathrm{HO}$ of which marks the base of Subzone KCN4a) ranges down into the Middle Campanian (unpublished work by RJC), and can look somewhat similar to C. gallica (especially when heavily overgrown), which we consider explains longer ranges of C. gallica recorded in other studies.

\section{Zone KCN4}

Definition. Interval from the LO of Lithraphidites praequadratus s. s. and Cribrocorona gallica to the $\mathrm{HO}$ of Reinhardtites levis.
Age. Early Late Maastrichtian.

Remarks. The LO of $L$. praequadratus is not used as a zonal marker in either of the zonations of Sissingh (1977) and Burnett (1998). Burnett (1998, fig. 6.5, p. 152) shows the FO of $L$. praequadratus in the mid-Campanian, much lower than we have found in this study.

\section{Subzone KCN4a}

Definition. Interval from the LO of Lithraphidites praequadratus s. $s$. and Cribrocorona gallica to the $\mathrm{HO}$ of Stoverius coangustatus n. sp.

Age. Early Late Maastrichtian. 
Upper Cretaceous biostratigraphy, offshore NW Australia

\section{Subzone KCN4b}

Definition. Interval from the HO of Stoverius coangustatus n. $\mathrm{sp}$. to the $\mathrm{HO}$ of Zeugrhabdotus bicrescenticus.

Age. Early Late Maastrichtian.

Remarks. This work confirms the placement of the HO of $Z$. bicrescenticus above the $\mathrm{HO}$ of Reinhardtites levis, as shown by Network Stratigraphic in Burnett (1998; fig. 6.6) and Bergen in Bergen \& Sikora (1999).

\section{Subzone KCN4c}

Definition. Interval from the HO of Zeugrhabdotus bicrescenticus to the HO of Reinhardtites levis.

Age. Earliest Late Maastrichtian.

\section{Zone KCN5}

Definition. Interval from the $\mathrm{HO}$ of Reinhardtites levis to the $\mathrm{HO}$ of Tranolithus phacelosus.

Age. Late Early Maastrichtian.

Remarks. KCN5 is missing in all of the sections examined in this study, except in Delta-1 and ODP Hole 762C, where short intervals (assigned to KCN5 or 6) above the HO of Aspidolithus parcus constrictus contain both $R$. levis and Z. bicrescenticus, as well as the planktonic foraminifer Abathomphalus mayaroensis (see KPF zonation below), suggesting that $R$. levis and $Z$. bicrescenticus are reworked, or that A. mayaroensis is caved or represents sample or laboratory contamination.

\section{Zone KCN6}

Definition. Interval from the $\mathrm{HO}$ of Tranolithus phacelosus to the $\mathrm{HO}$ of Aspidolithus parcus constrictus.

Age. Middle Early Maastrichtian.

Remarks. KCN6 is missing in all of the sections examined in this study, except for Delta-1 and ODP 762C (see Zone KCN5 above).

\section{Zone KCN7}

Definition. Interval from the $\mathrm{HO}$ of Aspidolithus parcus constrictus to the $\mathrm{HO}$ of Eiffellithus eximius.

Age. Latest Campanian to early Early Maastrichtian.

Remarks. A. parcus constrictus is inconsistent in occurrence in many of the sections examined in this study. It is associated with
Quadrum sissinghi, Q. trifidum, and $Q$. gothicum, which are much rarer and inconsistent in their occurrence.

Planktonic foraminiferal biostratigraphy

All taxa referred to in this section are illustrated in Plates 5-8.

\section{Zone KPF1}

Definition. Interval from the $\mathrm{HO}$ of Cretaceous planktonic foraminifera to the LO of Racemiguembelina fructicosa.

Age. Early Late to late Late Maastrichtian.

Remarks. This zone contains a diverse, abundant planktonic foraminiferal fauna dominated by heterohelicids and rugoglobigerinids, including Heterohelix globulosa, Heterohelix planata, Heterohelix rajagopalani, Laeviheterohelix glabrans, Planoglobulina acervulinoides, Pseudoguembelina palpebra, Pseudotextularia elegans, and Rugoglobigerina rugosa. Racemiguembelina fructicosa varies in abundance, but is consistently recorded. Keeled forms are represented by Abathomphalus mayaroensis, Globotruncana arca, Globotruncana falsostuarti, Globotruncanella petaloidea, Globotruncanita angulata, and Globotruncanita stuarti. The LO of $R$. fructicosa predates the LO of $C$. contusa, allowing the zone to be subdivided.

\section{Subzone KPF1a}

Definition. Interval from the $\mathrm{HO}$ of Cretaceous planktonic foraminifera to the LO of Contusotruncana contusa.

Age. Middle to late Late Maastrichtian.

Remarks. C. contusa is rare and sporadic in the Vulcan Sub-basin, but occurs more consistently on the Exmouth and Wombat Plateaus. It is more common towards the top of the zone.

\section{Subzone KPF1b}

Definition. Interval from the LO of Contusotruncana contusa to the LO of Racemiguembelina fructicosa.

Age. Middle Late Maastrichtian.

Remarks. A short duration for Subzone KPF1b is indicated by equivalent LOs for $C$. contusa and $R$. fructicosa in about half of the wells examined. It is also possible that a short hiatus is present with KPF1b.

\section{Zone KPF2}

Definition. Interval from the LO of Racemiguembelina fructicosa to the LO of Abathomphalus mayaroensis.

Age. Early Late Maastrichtian

Remarks. Abathomphalus mayaroensis is rare and somewhat sporadic near the base of its range in the Vulcan Sub-basin, but 


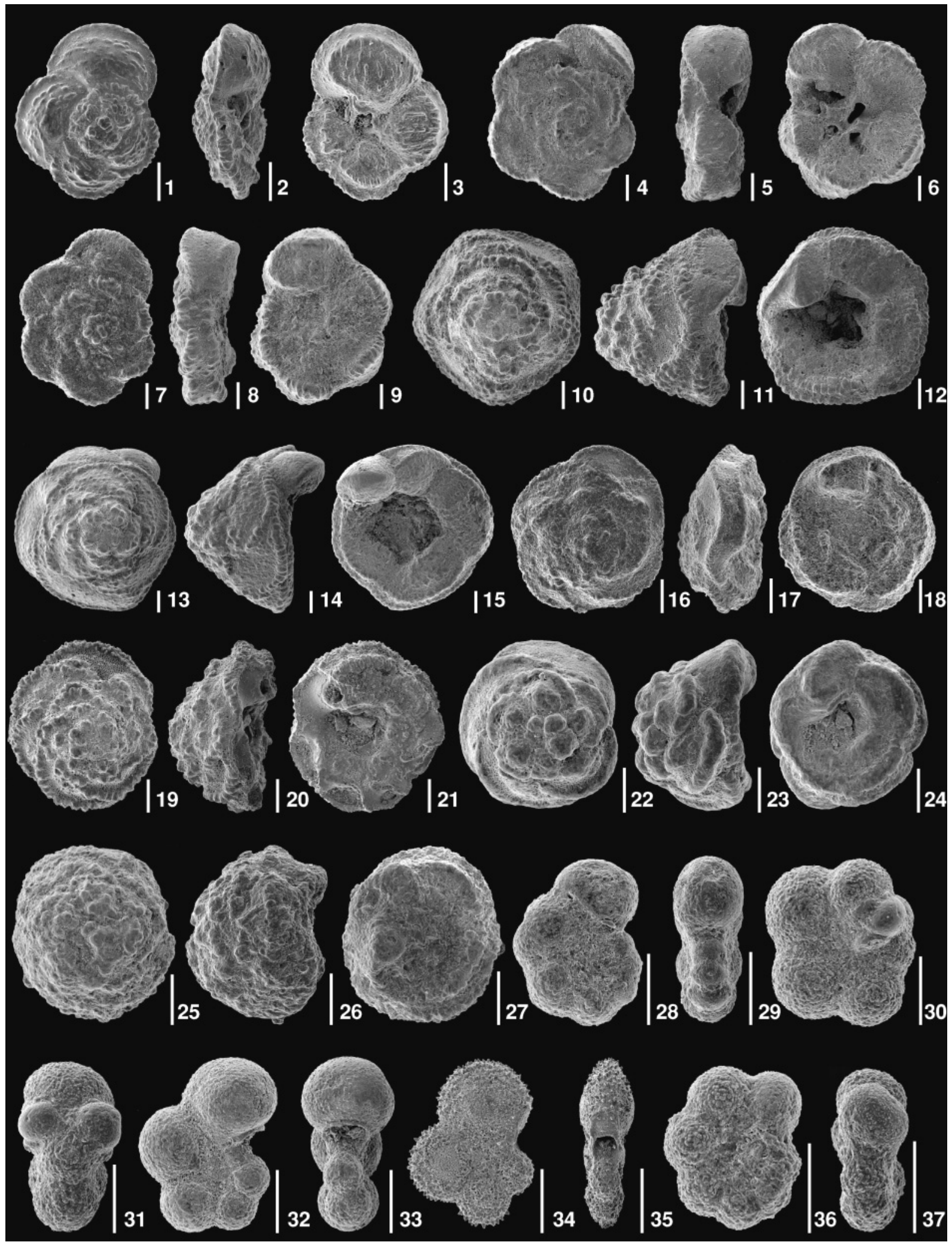

Explanation of Plate 5. All figures SEM (Scanning Electron Microscope) images. Scale bar equal to $0.1 \mathrm{~mm}$ on all figures. figs 1-3. Abathomphalus intermedius, ODP 761B-22X-3, $115 \mathrm{~cm}$. figs 4-6. Abathomphalus mayaroensis, ODP 761B-23X-5, 5-6 cm. figs 7-9. Abathomphalus mayaroensis, Parry 1, $2173 \mathrm{~m}$. figs 10-12. Contusotruncana contusa (angular morphotype), ODP 761B-21X-4, 144-145 cm. figs 13-15. Contusotruncana contusa (spherical morphotype), ODP 762C-43X-4, 45-46 cm. figs 16-18. Contusotruncana fornicata, Birch 1, $2208 \mathrm{~m}$. figs 19-21. Contusotruncana cf. patelliformis, ODP 761B-21X-5, 140-141 cm. figs 22-24. Contusotruncana cf. plicata, ODP 761B-21X-4, 144-145 cm. figs 25-27. Contusotruncana walfischensis, Parry 1, 2178.5 m. figs 28-29. Globigerinelloides cf. alvarezi, Birch 1, $2208 \mathrm{~m}$. figs 30-31. Globigerinelloides multispina, Swan 3ST, $2150 \mathrm{~m}$. figs 32-33. Globigerinelloides prairiehillensis, ODP 762C-48X-4, 40-41 cm. figs 34-35. Globigerinelloides subcarinatus, ODP 761B-24X-2, 110-111 cm. figs 36-37. Globigerinelloides ultramicra, Leeuwin 1, $1639 \mathrm{~m}$. 

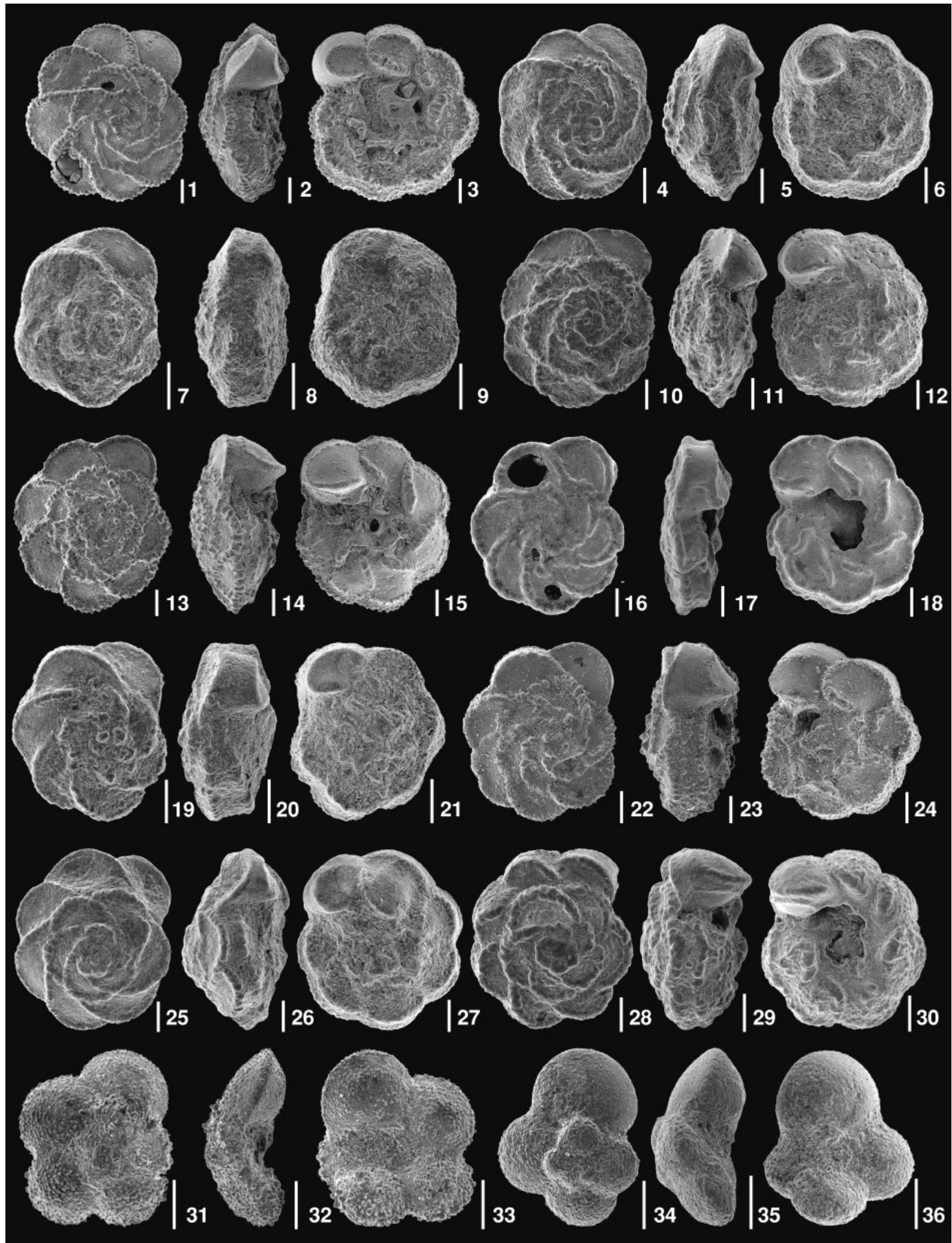

Explanation of Plate 6. All figures SEM images. Scale bar equal to $0.1 \mathrm{~mm}$ on all figures. figs 1-3. Globotruncana arca, ODP 761B-24X-2, 110-111 cm. figs 4-6. Globotruncana arca, Parry 1, $2256 \mathrm{~m}$. figs 7-9. Globotruncana bulloides, Rothbury 1, 2640 m. figs 10-12. Globotruncana dupeublei, Birch-1, $1987.3 \mathrm{~m}$. figs 13-15. Globotruncana falsostuarti, ODP 761B-24X-2, 110-111 cm. figs 16-18. Globotruncana linneiana, ODP 761B-25X-1, 120-122 cm. figs 19-21. Globotruncana linneiana, Swan 3ST, $2425 \mathrm{~m}$. figs 22-24. Globotruncana cf. linneiana, ODP 761B-24X-2, 110-111 cm. figs 25-27. Globotruncana orientalis, Parry 1, $2224 \mathrm{~m}$. figs 28-30. Globotruncana cf. ventricosa, ODP 761B-21X-4, 144-145 cm. figs 31-33. Globotruncanella havanensis, ODP 761B-21X-5, 140-141 cm. figs 34-36. Globotruncanella petaloidea, Parry 1, $2209 \mathrm{~m}$. 


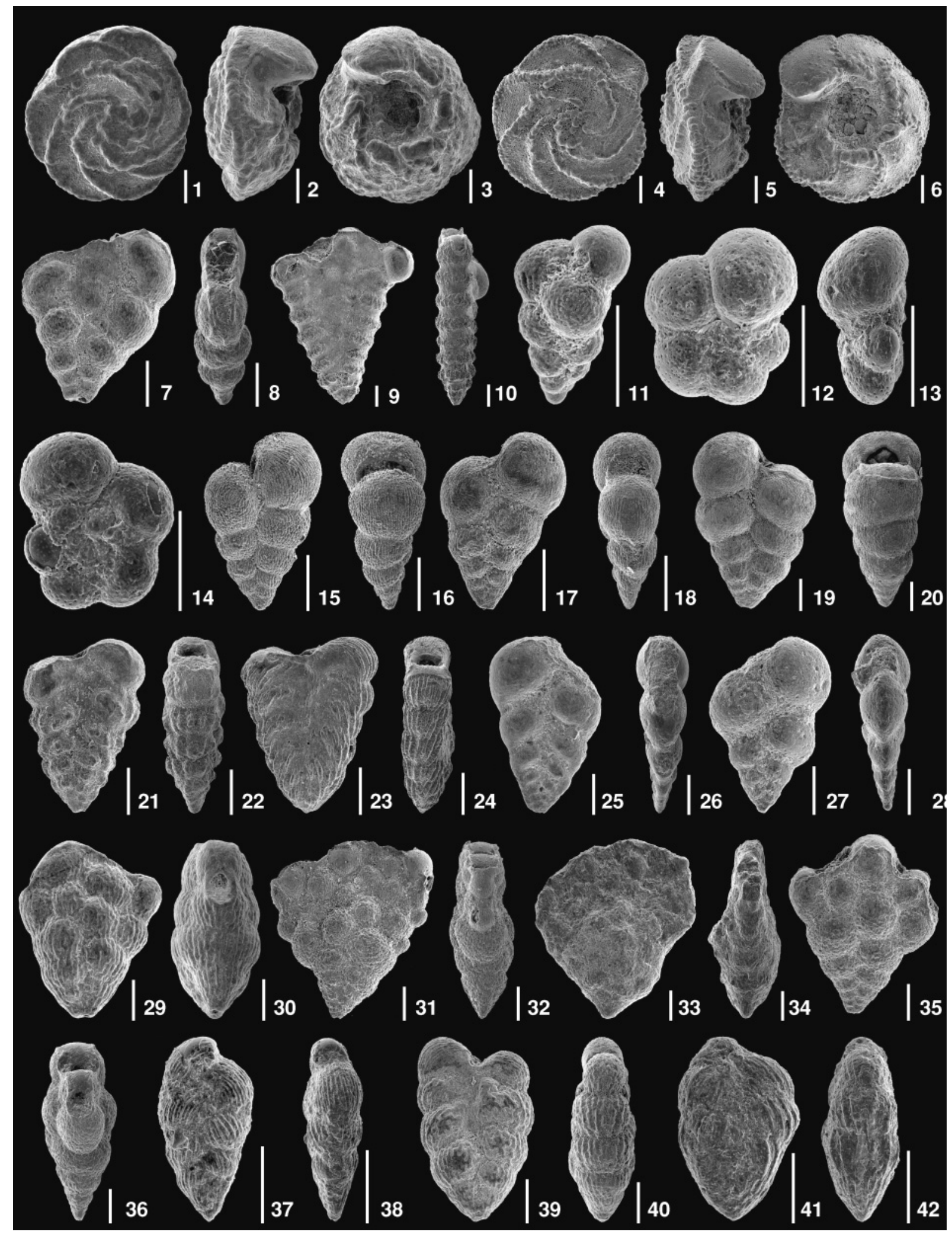

Explanation of Plate 7. All figures SEM images. Scale bar equal to $0.1 \mathrm{~mm}$ on all figures. figs 1-3. Globotruncanita angulata, ODP 761B-21X-4, 144-145 cm. figs 4-6. Globotruncanita stuarti, ODP 761B-21X-5, 140-141 cm. figs 7-8. Gublerina acuta, ODP 762C-46X-3, 116-117 cm. figs 9-10. Gublerina cuvillieri, ODP 761B-24X-2, 110-111 cm. fig. 11. Guembilitria cretacea, ODP 762C-46X-3, 116-117 cm. figs 12-14. Hedbergella cf. holmdelensis, Birch 1, $2184.8 \mathrm{~m}$. figs 15-16. Heterohelix globulosa, ODP 761B-22X-5, 106-107 cm. figs 17-18. Heterohelix planata, ODP 762C-46X-3, 116-117 cm. figs 19-20. Heterohelix cf. punctulata, ODP 761B-25X-2, 105-106 cm. figs 21-22. Heterohelix rajagopalani, ODP 762C-44X-4, 84-85 cm. figs 23-24. Heterohelix semicostata, ODP 761B-25X-2, 105-106 cm. figs 25-26. Laeviheterohelix cf. dentata, ODP 762C-47X-5, 106-107 cm. figs 27-28. Laeviheterohelix glabrans, Parry 1, $2209 \mathrm{~m}$. figs 29-30. Planoglobulina acervulinoides, ODP 761B-21X-4, 144-145 cm. figs 31-32. Planoglobulina multicamerata, ODP 761B-24X-2, 110-111 cm. figs 33-34. Planoglobulina multicamerata, Swan 3ST, $2320 \mathrm{~m}$. figs 35-36. Planoglobulina riograndensis, ODP 762C-46X-3, 116-117 cm. figs 37-38. Pseudoguembelina costulata, Swan 3ST, $2310 \mathrm{~m}$. figs 39-40. Pseudoguembelina palpebra, ODP 762C-44X-6, 66-67 cm. figs 41-42. Pseudoguembelina excolata, Swan 3ST, $2320 \mathrm{~m}$. 
is more common and consistent on the Exmouth and Wombat Plateaus. In this study, the LO of A. mayaroensis is found at consistently lower levels than the LOs of $R$. fructicosa and $C$. contusa. This contrasts with previous northwestern margin zonations (Wright \& Apthorpe, 1976; Wonders, 1992; Zepeda, 1998; and the original KPF zonation), and with the Tethyan zonation of Robaszynski \& Caron (1995). These studies record the LOs of $C$. contusa and $R$. fructicosa below the LO of $A$. mayaroensis. Planktonic foraminiferal abundance and diversity remains high within this zone, and most species found in KPF1 are represented.

\section{Subzone KPF2a}

Definition. Interval from the LO of Racemiguembelina fructicosa to the LO of Racemiguembelina powelli.

Age. Early Late Maastrichtian.

Remarks. Differentiation of $R$. fructicosa and $R$. powelli follows the taxonomy of Smith \& Pessagno (1973) and Nederbragt (1991), whereby $R$. fructicosa has four to five sets of multiserial chambers, and $R$. powelli has one to two sets of multiserial chambers. These forms are part of a lineage in which $R$. fructicosa and Pseudotextularia intermedia are end members.

\section{Subzone KPF2b}

Definition. Interval from the LO of Racemiguembelina powelli to the LO of Pseudotextularia intermedia.

Age. Early Late Maastrichtian

Remarks. Pseudotextularia intermedia is ancestral to $R$. powelli from which it differs by having only one pair of multiserial chambers, not connected by bridges, on the final chamber. An additional event within this subzone is the $\mathrm{HO}$ of the benthonic species Stensioeina pommerana.

\section{Subzone KPF2c}

Definition. Interval from the LO of Pseudotextularia intermedia to the LO of Abathomphalus mayaroensis.

Age. Early Late Maastrichtian

Remarks. A number of taxa appear to share a similar LO with A. mayaroensis. These species include Globotruncanita stuarti, Globotruncanita angulata, Planoglobulina acervulinoides, and Pseudoguembelina palpebra. In this study, the benthonic species Bolivinoides draco and Bolivinoides giganteus were not recorded below this level.

\section{Zone KPF3}

Definition. Interval from the LO of Abathomphalus mayaroensis to the HO of Globotruncana linneiana.

Age. Middle Early to earliest Late Maastrichtian.
Remarks. The planktonic foraminiferal diversity and abundance declines within this zone. Commonly recorded species include Rugoglobigerina rugosa, Heterohelix planata, Heterohelix rajagopalani, Laeviheterohelix glabrans, Guembelitria cretacea, and Globigerinelloides prairiehillensis. Keeled forms are less abundant than in the overlying zones. A reasonably strict taxonomic concept for Globotruncana linneiana was maintained throughout this study. Forms assigned to this species are flat and rectangular in profile, with a pair of broadly spaced parallel keels. Other forms which had a low trochospire, were slightly convex on the spiral side, and had a slightly tilted keel band were assigned to Globotruncana sp. cf. G. linneiana. These morphotypes ranged higher in the study area, and were recorded from beds assigned to Zone KPF1a. The benthonic species Stensioeina pommerana is most frequently recorded within this zone, and Bolivinoides miliaris is occasionally present.

\section{Zone KPF4}

Definition. Interval from the HO of Globotruncana linneiana to the LO of Gublerina cuvillieri.

Age. Middle Early Maastrichtian.

Remarks. The HO of Globotruncana bulloides is associated with the $\mathrm{HO}$ of G. linneiana. Gublerina cuvillieri is particularly rare and sporadic in the Vulcan Sub-basin, and often it is not possible to differentiate this zone from the older Zone KPF5. Planktonic foraminiferal diversity is lower in comparison to Zones KPF1 and KPF2, and species include Rugoglobigerina spp., Heterohelix spp., Globotruncana arca, Globigerinelloides spp. and Laeviheterohelix glabrans. Abathomphalus intermedius, ancestral to $A$. mayaroensis, is present, mainly in ODP Sites $761 \mathrm{~B}$ and $762 \mathrm{C}$. The benthonic species Bolivinoides delicatulus is consistently recorded from Zones KPF4 and KPF5.

\section{Zone KPF5}

Definition. Interval from the LO of Gublerina cuvillieri to the HO of Heterohelix semicostata.

Age. Latest Campanian to early Early Maastrichtian.

\section{Zone KPF6}

Definition. Total range of Heterohelix semicostata.

Age. Late Late Campanian.

Remarks. This zone was only recorded in ODP-762C, and was beyond the initial scope of this study. The LO of Heterohelix rajagopalani is possibly coincident with that of $H$. semicostata, and $G$. linneiana is abundant.

\section{Benthonic foraminiferal biostratigraphy}

Key taxa referred to in this section are illustrated in Plate 8, figs 31-39. 


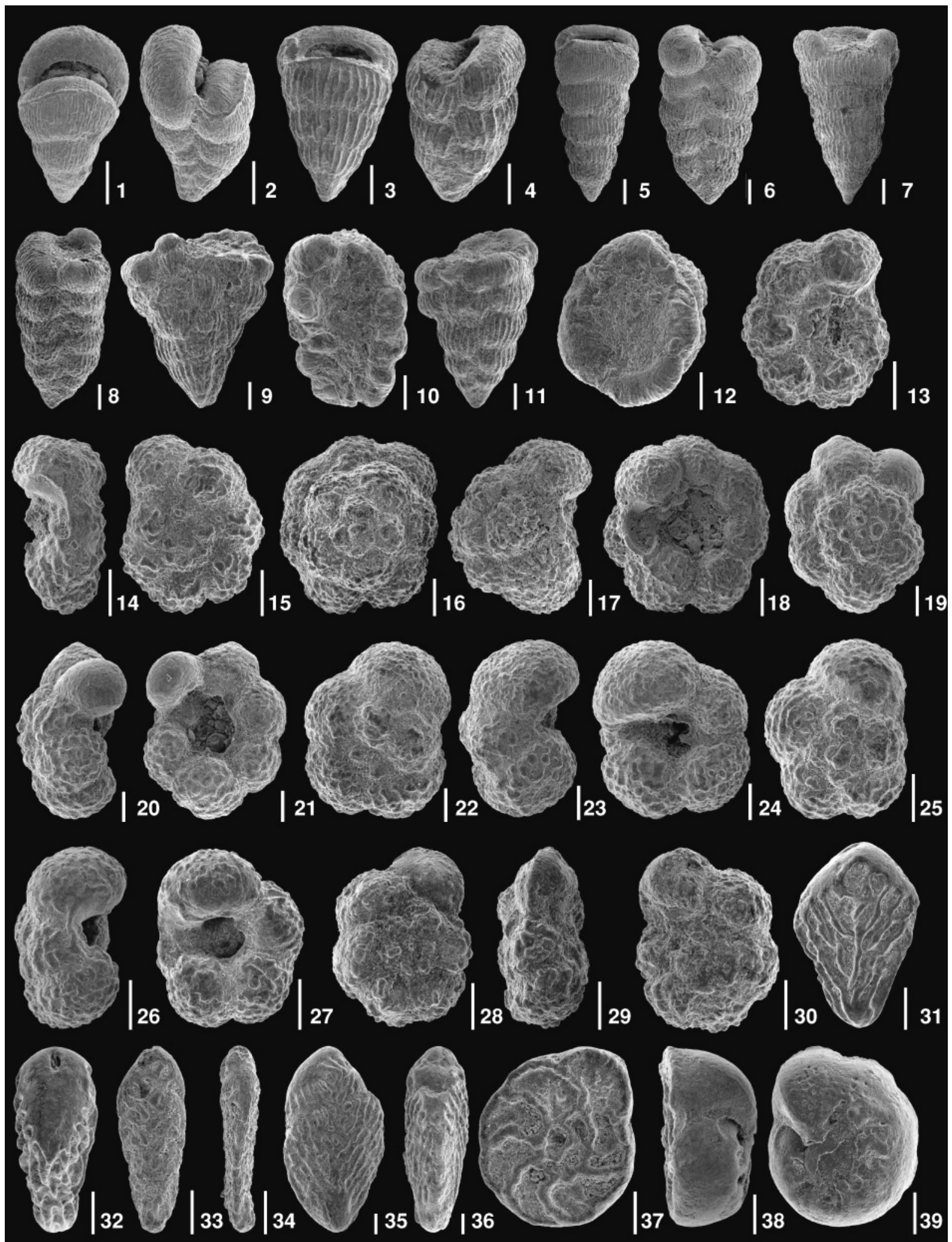

Explanation of Plate 8. All figures SEM images. Scale bar equal to $0.1 \mathrm{~mm}$ on all figures. figs 1-2. Pseudotextularia cushmani, ODP 761B-25X-2, 105-106 cm. figs 3-4. Pseudotextularia elegans (coarsely costate morphotype), ODP 762C-43X-4, 45-46 cm. figs 5-6. Pseudotextularia elegans (moderately costate morphotype), ODP 761B-24X-1, 110-111 cm. figs 7-8. Pseudotextularia intermedia, ODP 761B-24X-1, 110-111 cm. figs 9-10. Racemiguembelina fructicosa, Birch 1, $2090.3 \mathrm{~m}$. figs 11-12. Racemiguembelina powelli, Birch 1, $2090.3 \mathrm{~m}$. figs 13-15. Rugoglobigerina hexacamerata, ODP 762C-44X-6, 66-67 cm. figs 16-18. Rugoglobigerina milamensis, ODP 761B-23X-5, 5-6 cm. figs 19-21. Rugoglobigerina pennyi, ODP 762C-46X-3, 116-117 cm. figs 22-24. Rugoglobigerina rotundata, ODP 762C-43X-1, 95-96 cm. figs 25-27. Rugoglobigerina rugosa, ODP 761B-24X-3, 95-96 cm. figs 28-30. Rugotruncana subcircumnodifer, Parry 1, $2178.5 \mathrm{~m}$. figs 31-32. Bolivinoides draco, ODP 762C-44X-6, 66-67 cm. figs 33-34. Bolivinoides delicatulus, ODP 762C-44X-1, 85-86 cm. figs 35-36. Bolivinoides giganteus, Birch 1, $2048 \mathrm{~m}$. figs 37-39. Stensioeina pommerana, ODP $762 \mathrm{C}-47 \mathrm{X}-5,106-107 \mathrm{~cm}$ 
Upper Cretaceous biostratigraphy, offshore NW Australia

\section{Zone KBF1}

Definition. Total range of Bolivinoides draco.

Age. Middle Early to Late Maastrichtian.

Remarks. The LO of Bolivinoides draco occurs below the HO of Globotruncana linneiana (Rexilius, pers. comm., 2001). However, $B$. draco was not recorded below KPF2 in this study, possibly reflecting deeper water conditions.

Integrated calcareous microfossil zonation

\section{Zone KCCM1}

Definition. Interval from the $\mathrm{HO}$ of Cretaceous planktonic foraminifera to the LO of Ceratolithoides kamptneri.

Age. Late Late Maastrichtian.

\section{Subzone KCCM1a}

Definition. Interval from the $\mathrm{HO}$ of Cretaceous planktonic foraminifera to the LO of Micula prinsii.

Age. Latest Maastrichtian.

\section{Subzone KCCM1b}

Definition. Interval from the LO of Micula prinsii to the LO of Ceratolithoides kamptneri.

Age. Late Late Maastrichtian.

\section{Zone KCCM2}

Definition. Interval from the LO of Ceratolithoides kamptneri to the LO of Lithraphidites quadratus.

Age. Middle Late Maastrichtian.

\section{Subzone KCCM2a}

Definition. Interval from the LO of Ceratolithoides kamptneri to the LO of Micula murus.

Age. Middle Late Maastrichtian.

\section{Subzone KCCM2b}

Definition. Interval from the LO of Micula murus to the LO of Lithraphidites quadratus $s$. $s$.

Age. Middle Late Maastrichtian.

\section{Zone KCCM3}

Definition. Interval from the LO of Lithraphidites quadratus $s . s$. to the LO of Contusotruncana contusa.
Age. Middle Late Maastrichtian.

\section{Zone KCCM4}

Definition. Interval from the LO of Contusotruncana contusa to the LO of Racemiguembelina fructicosa.

Age. Middle Late Maastrichtian.

\section{Zone KCCM5}

Definition. Interval from the LO of Racemiguembelina fructicosa to the LOs of Lithraphidites praequadratus s. s. and Cribrocorona gallica.

Age. Middle Late Maastrichtian.

\section{Zone КСCM6}

Definition. Interval from the LOs of Lithraphidites praequadratus s. s. and Cribrocorona gallica to the $\mathrm{HO}$ of Reinhardtites levis.

Age. Early Late Maastrichtian.

\section{Subzone KCCM6a}

Definition. Interval from the LOs of Lithraphidites praequadratus s. s. and Cribrocorona gallica to the HO of Stoverius coangustatus n. sp.

Age. Early Late Maastrichtian.

\section{Subzone KCCM6b}

Definition. Interval from the HO of Stoverius coangustatus n. sp. to the LO of Racemiguembelina powelli.

Age. Early Late Maastrichtian.

\section{Subzone KCCM6c}

Definition. Interval from the LO of Racemiguembelina powelli to the LO of Pseudotextularia intermedia.

Age. Early Late Maastrichtian.

\section{Subzone KCCM6d}

Definition. Interval from the LO of Pseudotextularia intermedia to the LO of Abathomphalus mayaroensis.

Age. Early Late Maastrichtian.

\section{Subzone KCCM6e}

Definition. Interval from the LO of Abathomphalus mayaroensis to the HO of Zeugrhabdotus bicrescenticus. 
Age. Early Late Maastrichtian.

\section{Subzone KCCM6f}

Definition. Interval from the $\mathrm{HO}$ of Zeugrhabdotus bicrescenticus to the $\mathrm{HO}$ of Reinhardtites levis.

Age. Earliest Late Maastrichtian.

\section{Zone KCCM7}

Definition. Interval from the $\mathrm{HO}$ of Reinhardtites levis to the HOs of Tranolithus phacelosus and Quadrum trifidum.

Age. Late Early Maastrichtian.

\section{Zone KCCM8}

Definition. Interval from the HOs of Tranolithus phacelosus and Quadrum trifidum to the HO of Globotruncana linneiana.

Age. Middle Early Maastrichtian.

\section{Subzone KCCM8a}

Definition. Interval from the HO of Tranolithus phacelosus and Quadrum trifidum to the HO of Aspidolithus parcus constrictus.

Age. Middle Early Maastrichtian.

\section{Subzone KCCM8b}

Definition. Interval from the $\mathrm{HO}$ of Aspidolithus parcus constrictus to the $\mathrm{HO}$ of Globotruncana linneiana.

Age. Middle Early Maastrichtian.

\section{DISCUSSION}

\section{Late Campanian-early Late Maastrichtian disconformity}

Our results indicate a significant Late Campanian-early Late Maastrichtian disconformity/hiatus/condensed section, which, at its greatest duration, is between KCCM6 and KCCM11 (see Fig. 6). This event is most easily recognized by the HOs of Reinhardtites levis and Aspidolithus parcus constrictus which generally last co-occur within the same sample, closely above which the LOs of Abathomphalus mayaroensis and Lithraphidites praequadratus generally occur. This is the same event as the unconformity between the Campanian Korojon Calcarenite and Upper Maastrichtian Miria Marl in the Southern Carnarvon Basin, and the Campanian Lancelin Beds and the Upper Maastrichtian Breton Marl in the Perth Basin (Shafik, 1993). The mid-Maastrichtian disconformity within the Lancelin-1 Borehole in the Perth Basin, discussed by McNamara et al. (1988), would seem to be placed too high in the section, between the LOs of Lithraphidites quadratus and Lithraphidites praequadratus, whereas it should have been placed between the LO of $L$. praequadratus and the HOs of Reinhardtites levis and Aspidolithus parcus constrictus. The disconformity correlates to an interval of short-term sea-level fall during the Early Maastrichtian (Haq et al., 1987), however we do not regard sea-level fall as the direct cause of the disconformity, as the wells examined in this study were under bathyal $(>500 \mathrm{~m})$ waterdepths during the latest Campanian and Late Maastrichtian.

Shafik (1998) discussed ODP Holes 761B and 762C, and reinterpreted the calcareous nannofossil data of Bralower \& Siesser (1992) and the planktonic foraminiferal data of Wonders (1992). Shafik recognized the same disconformity as we do in Hole 762C, but not in Hole 761B. Golovchenko et al. (1992) discuss sedimentary cycles in Holes $761 \mathrm{~B}$ and $762 \mathrm{C}$, and interpret an upper Maastrichtian nondepositional event at c. $67 \mathrm{Ma}$, although this timing must be regarded as suspect, because none of the biostratigraphic or palaeomagnetic investigations in von Rad et al. (1992) recognized the presence of any Maastrichtian disconformity. Apthorpe (1979) suggested that a 'midMaastrichtian' disconformity (=Early Maastrichtian using the time-scale of Gradstein et al., 1994) is widespread on the western Australian margin, as she was unable to recognize Zone C12 (of mid-Maastrichtian age) in 45 of the 52 wells she studied.

The presence of the disconformity is uncertain in the Vulcan Sub-basin, where sampling gaps in the wells we examined are larger than in the ODP wells from the Exmouth Plateau, and where both nannofossils and foraminifera have significantly poorer preservation and lower abundances. Within the limits of sampling and sporadic fossil occurrences, the biostratigraphic sequence in the Vulcan Sub-basin wells is broadly similar to that of the ODP wells, suggesting that a disconformity in hemipelagic sediment between turbidite sands, or a condensed hemipelagic sequence between turbidite sands, may be present.

Isotopic and palaeoecological evidence suggests that a major reorganisation in ocean circulation patterns occurred near the Early-Late Maastrichtian boundary (Barrera, 1994; MacLeod, 1994b; Huber et al., 1995; MacLeod \& Huber, 1996; Barrera et al., 1997; Frank \& Arthur, 1999). Prior to reorganization, Cretaceous oceans had been characterized by relatively high temperatures, high sea-level, and a low-latitudinal temperature gradient (MacLeod, 1994b). High rates of evaporation at low latitudes and high temperatures at high latitudes resulted in sluggish, saline, low-oxygen bottom-water (MacLeod, 1994b). A gradual cooling trend in the Late Campanian and Early Maastrichtian intensified high-latitude formation of cold, oxygenated, bottom-waters and increased latitudinal temperaturegradients (Barrera, 1994; MacLeod \& Huber, 1996; Barrera et al., 1997). During this time, the Southern and Indian Oceans were isolated by geographical barriers between Antarctica and South America and in the central Atlantic, which inhibited the free circulation of intermediate to deep waters. As a result bottom-waters generated around Antarctica would have flowed north past the northwestern Australian margin into the Tethys Ocean. If these bottom waters were corrosive or if current strengths were high enough this could explain the widespread Early Maastrichtian hiatus found on the Western Australian margin. Near the Early-Late Maastrichtian boundary the geographical barrier formed by the Rio Grande Rise and Walvis Ridge in the Atlantic Ocean was breached by sea-floor spreading on the Mid-Atlantic Ridge, allowing freer circulation of bottomwaters between the North Atlantic and Indian Oceans (Frank \& Arthur, 1999). 
Upper Cretaceous biostratigraphy, offshore NW Australia

\section{Calcareous nannofossils}

Species commonly found in the material examined in this study include Arkhangelskiella spp., Cribrosphaerella ehrenbergii (which is abundant in almost all samples examined), Eiffellithus turriseiffelii (with less common E. parallelus and E. gorkae), Lithraphidites carniolensis (with much less common L. quadratus and L. praequadratus), Micula decussata (with less common M. cubiformis), Prediscosphaera cretacea (which is also abundant in almost all samples examined, with less common $P$. spinosa, $P$. majungae and rare $P$. grandis), Retecapsa spp., Watznaueria barnesae and Zeugrhabdotus spiralis. Nannofossil abundance was generally high to very high in the ODP holes, and low to moderate in the wells from the Vulcan Sub-basin. Many of the turbidite sands in the Vulcan Sub-basin are barren of nannofossils. Nannofossil preservation was generally moderate to good, particularly in the ODP holes.

In all of the sections examined Micula murus and $M$. prinsii are very rare and sporadic. These species are interpreted to have Tethyan affinities (Thierstein, 1981; Henriksson, 1993), so the study area is probably close to the southern limit of their distribution. Therefore, the absence of these species above the LO of Lithraphidites quadratus should not be taken to mean that Subzones KCN1a and 1b are definitely not present. The distinction between $L$. praequadratus and L. quadratus, following the morphometric criteria of Roth (1978), see Figure 7, is critical in separating Zones KCN2 and 3.

Petrarhabdus vietus is found to have a $\mathrm{HO}$ at the same level as the LO of Lithraphidites praequadratus. Exactly when, and how, the transition from $P$. copulatus to $P$. vietus occurred is unknown, as $P$. copulatus is present only below the uppermost Campanian-Lower Maastrichtian disconformity. Podorhabdus? elkefensis is a little-recorded species which ranges throughout the interval examined in this study. It is not present in ODP Holes $761 \mathrm{~B}$ and $762 \mathrm{C}$, and is rare and sporadic in occurrence in all of the other sections examined. This suggests that this species prefers more proximal environments, with higher siliciclastic sediment input.

Ceratolithoides aculeus is consistently present in moderate abundances in the Upper Campanian below the unconformity, is rare and sporadic in $\mathrm{KCN} 3$ and 4, and very rare in $\mathrm{KCN} 1$ and 2, suggesting an upward cooling trend, as $C$. aculeus is well known to have Tethyan affinities (Burnett, 1997a). C. indiensis is rarer and more sporadic in its occurrence than $C$. aculeus, and is very rare above $\mathrm{KCN} 3$. It is much more common in ODP Hole 761B than Hole 762C, suggesting that this species is also Tethyan in affinity. In the wells examined from the Vulcan Sub-basin, $C$. indiensis is the most common species of Ceratolithoides after $C$. aculeus, but is still rare and sporadic in occurrence. This might suggest that it preferred more distal environments, but equally its occurrence could be due to the generally much lower abundances and poorer preservation of the Vulcan Sub-basin wells compared to the ODP holes. Quadrum trifidum, Q. sissinghii, and $Q$. gothicum are known to have Tethyan distributions (Thierstein, 1981), and all have very rare and sporadic occurrences in this study, suggesting that the northwestern Australian margin was near the southern limit of their distribution during the latest Campanian.

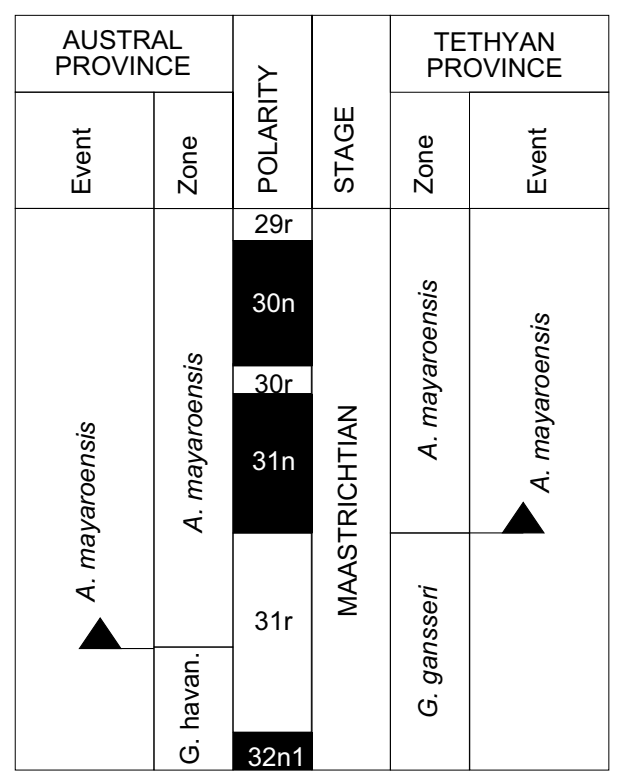

Fig. 8. Comparison of the lowest occurrence of Abathomphalus mayaroensis in the high-latitude Austral Province (from Huber, 1990), and the low-latitude Tethyan Province (from Premoli Silva \& Sliter, 1994).

\section{Planktonic foraminifera}

In Tethyan biostratigraphic schemes, the LO of Contusotruncana contusa predates the LO of Abathomphalus mayaroensis and defines the $C$. contusa Zone (Dalbiez, 1955; Pessagno, 1967; Van Hinte, 1976; Wonders, 1980; Premoli Silva \& Sliter, 1994; Robaszynski \& Caron, 1995). Similarly, the LO of Racemiguembelina fructicosa occurs below the LO of $A$. mayaroensis, at about the same level as the LO of C. contusa (Sigal, 1977; Nederbragt, 1991; Premoli Silva \& Sliter, 1994). The results of this study of the Exmouth Plateau and the Vulcan Sub-basin indicate a different sequence of events, with the LOs of $C$. contusa and $R$. fructicosa consistently postdating the LO of Abathomphalus mayaroensis. In addition, Gansserina gansseri, the LO of which defines the base of a zone in the Tethyan Realm (see Sigal, 1977; Robaszynski \& Caron, 1995), is absent from the sections examined in this study.

This contrast between the ranges of $C$. contusa, $R$. fructicosa, A. mayaroensis and $G$. gansseri is palaeobiogeographically driven, with the northwestern Australian margin lying in a transitional setting between the Tethyan and Austral Realms. The LO of A. mayaroensis has been shown to be a diachronous event, with the species originating at high latitudes (Austral Realm) near the Early-Late Maastrichtian boundary and then migrating equator-ward (Huber 1990, 1991, 1992; Nederbragt, 1998; Frank \& Arthur, 1999). In high southern latitude Austral sites, the LO of $A$. mayaroensis occurs within the middle of magnetic Chron 31R (Huber, 1990, 1991, 1992), whereas in low-latitude Tethyan settings such as Gubbio, Italy (Premoli Silva \& Sliter, 1994), and the equatorial Pacific (Boersma, 1981) it first occurs in Chron $31 \mathrm{~N}$ (Fig. 8).

In contrast to $A$. mayaroensis, which appears to have originated at high latitudes, Tethyan species such as $C$. contusa, $G$. gansseri and $R$. fructicosa are absent from Austral sections (e.g. Huber, 1990, 1991: Kerguelen Plateau and Weddell Sea, Southern Ocean; Webb, 1973: Lord Howe Rise, Tasman Sea; 
Hornibrook et al., 1989: New Zealand). The transitional setting of the northwestern Australian margin was likely to be near the palaeolatitudinal limit of some Tethyan species such as $R$. fructicosa and C. contusa (see Kucera \& Malmgren, 1996), and outside the palaeolatitudinal limit of other Tethyan species such as G. gansseri. Of interest is that Chungkham \& Jafar (1998) record $G$. gansseri from Ukhrul, northeastern India, estimated to have a palaeolatitude of between $20^{\circ} \mathrm{S}$ and $30^{\circ} \mathrm{S}$ during the Maastrichtian. Wonders (1992) suggested that C. contusa was an immigrant to the northwestern Australian margin and that its appearance in that area postdates its evolutionary appearance elsewhere. Probably of equal importance to the sequence of events recorded on the margin was the northward migration of $A$. mayaroensis and the resultant earlier LO for this species than in the Tethyan Realm.

Whatever the reason for the difference in the sequence of events, the results of this study call into question the validity of the C. contusa Zone recorded by previous workers on the northwestern Australian margin. Both Wonders (1992) and Zepeda (1998) record the C. contusa Zone from ODP 762C, but neither record $C$. contusa below $A$. mayaroensis. The assignment of samples to the $C$. contusa Zone is based instead on the LO of Abathomphalus intermedius, which was used by these workers as a proxy for $C$. contusa. In a separate study of petroleum wells on the northwestern Australian margin, Wright \& Apthorpe (1976) also defined a $C$. contusa Zone, with the LO of $C$. contusa as the base and the LO of $A$. mayaroensis marking the upper boundary of the zone. Apthorpe (1979) later highlighted problems with applying this zone to the region and questioned the validity of the LO of $C$. contusa as an event, or whether the absence of this species below $A$. mayaroensis marked a middle Maastrichtian disconformity. In our study, the LOs of $R$. fructicosa and $C$. contusa predate the LO of $A$. mayaroensis in only two wells, Leeuwin-1 and Rothbury-1, situated in the Vulcan Sub-basin, where A. mayaroensis was both rare and sporadic. The samples in these wells which contained $R$. fructicosa and $C$. contusa without $A$. mayaroensis also contained the nannofossil Lithraphidites praequadratus, the LO of which is found to postdate the LO of A. mayaroensis in all other wells studied in the area. As a result it appears that the $C$. contusa Zone is not valid in the study area.

The contrast between the Tethyan and Transitional Province ranges of $A$. mayaroensis has meant considerable revision to the Late Maastrichtian part of the KPF planktonic foraminiferal zonation. Where previously the base of the KPF1 Zone was identified by the LO of A. mayaroensis(Rexilius, unpublished data), it is now defined by the LO of $R$. fructicosa. Similarly, where previously the base of the original KPF2 Zone was identified by the LO of $R$. fructicosa, it is now defined by the stratigraphically older placement for the LO of $A$. mayaroensis (Fig. 6).

\section{CONCLUSIONS}

Three biostratigraphic zonations are presented for the latest Campanian-Maastrichtian of the Exmouth Plateau and Vulcan Sub-basin, on the northwestern Australian margin, using planktonic foraminifera and calcareous nannofossils. These zonations are revisions of the unpublished $\mathrm{KCN}$ (nannofossils), KPF (planktonic foraminifera), and KCCM (combined nannofossils and foraminifera) zonations. The northwestern Australian margin clearly lay within a diffuse Transitional Province between the warm Tethyan Province to the north and the cool Austral Province to the south. Species of both foraminifera and nannofossils with Tethyan affinities are present with species with Austral affinities. In the KCN zonation, the use of Tethyan species such as Micula murus, M. prinsii, and Ceratolithoides kamptneri is difficult as these species are often rare and sporadic in their distribution. In the KPF zonation, the use of a Contusotruncana contusa Zone or Racemiguembelina fructicosa Zone predating the Abathomphalus mayaroensis Zone was shown to be invalid in the Transitional setting of the northwestern margin. This is probably due to the equator-ward migration of $A$. mayaroensis from the south resulting in an older LO in comparison to Tethyan sections, and/or a later migration of $C$. contusa and $R$. fructicosa into the area.

Revision of the zonations has highlighted a major disconformity, separating Upper Campanian from lower Upper Maastrichtian strata. This disconformity was largely unnoticed in previous examinations of ODP material from Exmouth Plateau, but was recorded by previous workers on the northwestern Australian margin (e.g. Apthorpe, 1979; Shafik, 1993).

\section{ACKNOWLEDGEMENTS}

This project was carried out at the University of Western Australia and was funded as a project of the Virtual Centre of Economic Micropalaeontology and Palynology (VCEMP) by the Australian Geological Survey Organisation (AGSO). We thank Clinton Foster of AGSO for his strong support of the project. David Haig, Marjorie Apthorpe, Barry Taylor, Warwick Crowe and Fiona Burns are thanked for their helpful advice during the project. The curatorial staff of the Ocean Drilling Program at Texas A\&M University are thanked for their supply of samples from ODP Holes 761B and 762C. The staff at the Centre for Microscopy and Microanalysis, UWA, are thanked for access to the Scanning Electron Microscope.

\section{APPENDIX A: TAXONOMIC NOTES}

\section{(with James A. Bergen, BP America, Houston, TX, USA) \\ Rotelapillus laffittei (Nöel, 1956) Howe comb. nov.}

Basionym. Stephanolithion laffittei Nöel (1956), p. 318, pl. 2, fig 5 , non fig. 6.

Reference. Nöel (1956).

Discussion. Nöel (1973) is frequently cited (e.g. Bown, 1998) as having recombined Stephanolithion laffittei Nöel (1956) into Rotelapillus Noel (1973). Nöel (1973) does not actually contain such a recombination, so it is made here.

\section{Stoverius coangustatus n. sp. Howe, Bergen \& Campbell}

$$
\text { (P1. 4, figs 3, 4). }
$$

Derivation of name. Latin - coangusto: compress, confine, enclose. 
Holotype. Plate 4, fig. 4. Paratype Plate 4, fig. 3.

Type locality. Ocean Drilling Program Hole 761B, on the Exmouth Plateau, offshore of northwestern Australia. The holotype is from sample ODP761B-25X-1, $120 \mathrm{~cm}$, and the paratype is from sample ODP761B-24X-2, $110 \mathrm{~cm}$.

Type level. The holotype belongs to Zone KCN7 of this study, Zone UC16 of Burnett (1998), Subzone CC23a of Sissingh (1977) and is of late Late Campanian age. The paratype belongs to subzones KCN4b and KCCM6c of this study, Zone UC19 of Burnett (1998), Subzone CC25a of Sissingh (1977), and is of early Late Maastrichtian age.

Diagnosis. A circular to subcircular species of Stoverius with a small central area spanned by two arcuate bars.

Description (light microscope). A medium-sized (holotype $7.2 \mu \mathrm{m}$ diameter, paratype $6.7 \mu \mathrm{m}$, typical range $5.5-7.5 \mu \mathrm{m})$, circular to subcircular protolith constructed of two rim cycles. The broad proximal rim cycle is low and constructed of 24-36 radial elements with convex peripheries. These elements exhibit a first-order grey to white birefringence. The distal rim cycle is high and composed of radial elements, with a smooth periphery. The distal rim cycle exhibits a bright first-order yellow-orange to orange birefringence. The width of the distal rim cycle is variable (c. $5 \mu \mathrm{m}$ diameter in the holotype), being between $50-95 \%$ the width of the proximal rim cycle. A low, narrow wall (c. $1.7 \mu \mathrm{m}$ wide in the holotype) connects the two rim cycles and can be seen upon proximal focus; it exhibits a first-order white birefringence. The central area is small (c. $2.7 \mu \mathrm{m}$ wide in the holotype), occupying between onethird to one-fifth of the coccolith diameter or width. Two arcuate bars span the small central opening and are orientated with their convex sides facing each other and are joined near the centre; these bars are faintly birefringent, and are rarely preserved.

Occurrence. This species is restricted to the Middle Campanian to lower Upper Maastrichtian on the Northwest Shelf. It has a well-defined highest occurrence in the lower Upper Maastrichtian, approximately coincident with the lowest occurrence of Lithraphidites praequadratus, and a well-defined lowest occurrence in the Middle Campanian, at about the same level as the lowest occurrence of Ceratolithoides aculeus (unpublished work by RJC).It is also present in Tunisia and the CampanianMaastrichtian boundary stratotype near Tercis, France (unpublished work by JAB) and also on the Scotian Shelf, offshore eastern Canada (unpublished work by RWH).

Discussion. This species differs from other species of Stoverius in having a smaller central area, and a broader proximal rim cycle. $S$. coangustatus evolved from $S$. biarcus during the middle Campanian through restriction of the central area. S. coangustatus is distinguished from Cylindralithus crassus by having a central structure and a less birefringent distal rim cycle.

Zeughrabdotus minimus (Bukry, 1969) Howe comb. nov.

Basionym. Zygodiscus minimus Bukry (1969), p. 61, pl. 35, figs 9-11.
Reference. Bukry (1969).

Discussion. Zygodiscus is a Palaeocene and Lower Eocene genus with two cycles of elements in its outer wall (following the terminology of Young et al., 1997), while the Mesozoic genus Zeugrhabdotus has a single cycle of elements in its outer wall. As Zygodiscus minimus is a Late Cretaceous species which appears to have a single cycle of elements in its outer wall, it is recombined into Zeugrhabdotus.

Zeughrabdotus wynnhayi (Risatti, 1973) Howe comb. nov.

Basionym. Zygodiscus wynnhayi Risatti (1973), p. 22, pl. pl. 9, figs, 21, 22.

Reference. Risatti (1973).

Discussion. See discussion for Zeugrhabdotus minimus above.

\section{APPENDIX B: ALPHABETICAL LIST OF SPECIES CONSIDERED IN THIS STUDY}

Calcareous nannofossils

References not cited in this paper can be found in Perch-Nielsen (1985) and Bown (1998).

Ahmuellerella octoradiata (Gorka, 1957) Reinhardt (1966)

Ahmuellerella regularis (Gorka, 1957) Reinhardt \& Gorka (1967)

Angulofenestrellithus snyderi Bukry (1969)

Arkhangelskiella confusa Burnett (1998b)

Arkhangelskiella cymbiformis Vekshina (1959)

Aspidolithus parcus (Stradner, 1963) Nöel (1969) ssp. constric-

tus (Hattner et al., 1980) Perch-Nielsen (1984)

Aspidolithus parcus (Stradner, 1963) Nöel (1969) ssp. parcus

(Stradner, 1963) Nöel (1969)

Biscutum constans (Gorka, 1957) Black in Black \& Barnes (1959)

Biscutum ellipticum (Gorka, 1957) Grün in Grün \& Allemann (1975)

Biscutum zulloi Covington (1994)

Braarudosphaera bigelowii (Gran \& Braarud, 1935) Deflandre (1947)

Broinsonia signata (Nöel, 1969) Nöel (1970)

Calculites obscurus (Deflandre, 1959) Prins \& Sissingh in Sissingh (1977)

Ceratolithoides aculeus (Stradner, 1961) Prins \& Sissingh in Sissingh (1977)

Ceratolithoides amplector Burnett (1998a)

Ceratolithoides arcuatus Prins \& Sissingh in Sissingh (1977)

Ceratolithoides indiensis Burnett (1998a)

Ceratolithoides kamptneri Bramlette \& Martini (1964)

Ceratolithoides pricei Burnett (1998a)

Ceratolithoides prominens Burnett (1998a)

Ceratolithoides quasiarcuatus Burnett (1998a)

Ceratolithoides self-trailae Burnett (1998a)

Ceratolithoides ultimus Burnett (1998a)

Chiastozygus amphipons (Bramlette \& Martini, 1964) Gartner (1968) 
Chiastozygus antiquus (Perch-Nielsen, 1973) Burnett (1998b)

Corollithion completum Perch-Nielsen (1973)

Corollithion exiguum Stradner (1961)

Corollithion madagaskarensis Perch-Nielsen (1973)

Cretarhabdus conicus Bramlette \& Martini (1964)

Cretarhabdus multicavus Bukry (1969)

Cribrocorona gallica (Stradner, 1963) Perch-Nielsen (1973)

Cribrosphaerella circula (Risatti, 1973)

Cribrosphaerella daniae Perch-Nielsen (1973)

Cribrosphaerella ehrenbergii (Arkhangelsky, 1912) Deflandre in Piveteau (1952)

Cyclagelosphaera reinhardtii (Perch-Nielsen, 1968) Romein (1977)

Cylindralithus sp. 2

Discorhabdus ignotus (Gorka, 1957) Perch-Nielsen (1968)

Eiffellithus eximius (Stover, 1966) Perch-Nielsen (1968)

Eiffellithus gorkae Reinhardt (1965)

Eiffellithus parallelus Perch-Nielsen (1973)

Eiffellithus turriseiffellii (Deflandre in Deflandre \& Fert,

1954) Reinhardt (1965)

Gartnerago obliquum (Stradner, 1963) Nöel (1970)

Gorkaea pseudanthophorus (Bramlette \& Martini, 1964) Varol

\& Girgis (1994)

Helicolithus trabeculatus (Gorka, 1957) Verbeek (1977)

Kamptnerius magnificus Deflandre (1959)

Lithraphidites carniolensis Deflandre (1963)

Lithraphidites praequadratus Roth (1978)

Lithraphidites quadratus Bramlette \& Martini (1964) emend. Roth (1978)

Loxolithus sp. 1 Bergen in Bralower \& Bergen (1998)

Loxolithus sp. 2 Bergen in Bralower \& Bergen (1998)

Loxolithus teneraretis (Varol, 1991) Howe in Howe et al. (2000)

Lucianorhabdus cayeuxii Deflandre (1959)

Maniviitella pemmatoidea (Deflandre in Manivit, 1965)

Thierstein (1971)

Markalius inversus (Deflandre in Deflandre \& Fert, 1954)

Bramlette \& Martini (1964)

Microrhabdulus attenuatus (Deflandre, 1959) Deflandre (1963)

Microrhabdulus belgicus Haye \& Towe (1963)

Microrhabdulus decoratus Deflandre (1959)

Microrhabdulus helicoideus Deflandre (1959)

Micula cubiformis Forchheimer (1972)

Micula decussata Vekshina (1959)

Micula murus (Martini, 1961) Bukry (1973)

Micula praemurus (Bukry, 1973) Stradner \& Steinmetz (1984)

Micula prinsii Perch-Nielsen (1979)

Misceomarginatus pleniporus Wind \& Wise in Wise \& Wind (1977)

Nephrolithus corystus Wind (1983)

Nephrolithus frequens Gorka (1957)

Octolithus multiplus (Perch-Nielsen, 1973) Romein (1979)

Pervilithus varius Crux (1981) (=Scampanella sp. in end-on view)

Petrarhabdus copulatus (Deflandre, 1959) Wind \& Wise in Wise (1983)

Petrarhabdus vietus Burnett (1998b)
Petrobrasiella bownii Burnett (1998b)

Podorhabdus? elkefensis Perch-Nielsen (1981)

Prediscosphaera arkhangelskyii (Reinhardt, 1965) Perch-

Nielsen (1984)

Prediscosphaera cretacea (Arkhangelsky, 1912) Gartner (1968)

Prediscosphaera grandis Perch-Nielsen (1979)

Prediscosphaera majungae Perch-Nielsen (1973)

Prediscosphaera spinosa (Bramlette \& Martini, 1964) Gartner (1968)

Prolatipatella multicarinata Gartner (1968)

Pseudomicula quadrata Perch-Nielsen in Perch-Nielsen et al. (1978)

Psyktosphaera firthii Pospichal \& Wise (1990)

Quadrum bengalensis Burnett (1998b)

Quadrum gothicum (Deflandre, 1959) Prins \& Perch-Nielsen in

Manivit et al. (1977)

Quadrum sissinghii Perch-Nielsen (1984)

Quadrum trifidum (Stradner in Stradner \& Papp, 1961) Prins

\& Perch-Nielsen in Manivit et al. (1977)

Reinhardtites levis Prins \& Sissingh in Sissingh (1977)

Retecapsa schizobrachiata (Gartner, 1968) Grün in Grün \&

Allemann (1975)

Retecapsa spp.

Rhagodiscus angustus (Stradner, 1963) Reinhardt (1971)

Rhagodiscus plebius Perch-Nielsen (1968)

Rhagodiscus reniformis Perch-Nielsen (1973)

Rhagodiscus splendens (Deflandre, 1953) Verbeek (1977)

Rotelapillus laffittei (Nöel, 1956) Howe comb. nov.

Rucinolithus hayi Stover (1966)

Rucinolithus sp. 8

Russellia bukryi Risatti (1973)

Scampanella spp.

Scapholithus fossilis Deflandre in Deflandre \& Fért (1954)

Semihololithus priscus Perch-Nielsen (1973)

Staurolithites ellipticus (Gartner, 1968) Lambert (1987)

Staurolithites imbricatus (Gartner, 1968) Burnett (1998b)

Staurolithites laffittei Caratini (1963)

Staurolithites mielnicensis (Gorka, 1957) Perch-Nielsen (1968)

Staurolithites stradneri (Rood et al., 1971) Bown (1998)

Stoverius coangustatus n. sp.

Tegumentum stradneri Thierstein in Roth \& Thierstein (1972)

Tetrapodorhabdus decorus (Deflandre in Deflandre \& Fert,

1954) Wind \& Wise in Wise \& Wind (1977)

Tranolithus phacelosus Stover (1966)

Watznaueria barnesae (Black, 1959) Perch-Nielsen (1968)

Watznaueria ovata Bukry (1969)

Zeughrabdotus bicrescenticus (Stover, 1966) Burnett in Gale et al. (1996)

Zeughrabdotus embergeri (Nöel, 1958) Perch-Nielsen (1984)

Zeughrabdotus minimus (Bukry, 1969) Howe comb. nov.

Zeughrabdotus praesigmoides Burnett (1998b)

Zeughrabdotus spiralis (Bramlette \& Martini, 1961) Burnett (1998b)

Zeughrabdotus tarboulensis (Shafik \& Stradner, 1971) Howe in Howe et al. (2000)

Zeughrabdotus cf. trivectis Bergen (1994)

Zeughrabdotus wynnhayi (Risatti, 1973) Howe comb. nov. 


\section{Planktonic foraminifera}

Original generic assignment is quoted in square brackets to allow for quick reference to the original citation within the catalogue of Ellis \& Messina (1945 et seq.). References not cited in this paper can be found in Ellis \& Messina (1945 et seq.) and Caron (1985).

Abathomphalus intermedius (Bolli, 1951) [Globotruncana] Abathomphalus mayaroensis (Bolli, 1951) [Globotruncana] Contusotruncana contusa (Cushman, 1926) [Pulvinulina arca var.]

Contusotruncana fornicata (Plummer, 1931) [Globotruncana]

Contusotruncana patelliformis (Gandolfi, 1955) [Globotruncana contusa subsp.]

Contusotruncana cf. plicata (White, 1928) [Globotruncana conica var.]

Contusotruncana walfischensis (Todd, 1970) [Globotruncana]

Globigerinelloides cf. alvarezi (Eternod Olvera, 1959) [Planomalina]

Globigerinelloides multispina (Lalicker, 1948) [Biglobigerinella]

Globigerinelloides prairiehillensis Pessagno, 1967

Globigerinelloides subcarinatus (Brönnimann, 1952) [Globigerinella messinae subsp.]

Globigerinelloides ultramicra (Subbotina, 1949) [Globigerinella]

Globotruncana cf. aegyptiaca Nakkady, 1950

Globotruncana arca (Cushman, 1926) [Pulvinulina]

Globotruncana bulloides Vogler, 1941 [Globotruncana linnei subsp.]

Globotruncana dupeublei Caron, Gonzalez Donoso,

Robaszynski, \& Wonders, 1984

Globotruncana cf. esnehensis Nakkady, 1950 [Globotruncana arca var.]

Globotruncana falsostuarti Sigal, 1952

Globotruncana insignis Gandolfi, 1955

Globotruncana linneiana (d'Orbigny), 1839 [Rosalina]

Globotruncana orientalis El Nagger, 1966

Globotruncana rugosa (Marie, 1941) [Rosalinella]

Globotruncana ventricosa White, 1928 [Globotruncana canaliculata var.]

Globotruncanella havanensis (Voorwijk, 1937) [Globotruncana] Globotruncanella petaloidea (Gandolfi, 1955) [Globotruncana] Globotruncanita angulata (Tilev, 1951) [Globotruncana lugeoni var.]

Globotruncanita cf. conica (White, 1928) [Globotruncana]

Globotruncanita cf. pettersi (Gandolfi, 1955) [Globotruncana rosetta subsp.]

Globotruncanita stuarti (de Lapparent, 1918) [Rosalina]

Gublerina acuta De Klasz, 1953

Gublerina cuvillieri Kikoine, 1948

Guembilitria cretacea Cushman, 1933

Hedbergella $\mathrm{cf}$. holmdelensis Olsson, 1964

Heterohelix globulosa (Ehrenberg, 1840) [Textularia]

Heterohelix planata (Cushman, 1938) [Guembelina]

Heterohelix cf. punctulata (Cushman, 1938) [Guembelina]

Heterohelix rajagopalani (Govindan, 1970) [Gublerina]

Heterohelix semicostata (Cushman, 1938) [Guembelina]

Laeviheterohelix cf. dentata (Stenestad, 1968) [Heterohelix]

Laeviheterohelix glabrans (Cushman, 1938) [Guembelina]

Planoglobulina acervulinoides (Egger, 1899) [Guembelina]
Planoglobulina cf. carseyae (Plummer, 1931) [Ventilabrella]

Planoglobulina multicamerata (De Klasz, 1953) [Ventilabrella]

Planoglobulina riograndensis (Martin, 1972) [Ventilabrella]

Pseudoguembelina costulata (Cushman, 1938) [Guembelina]

Pseudoguembelina excolata (Cushman, 1926) [Guembelina]

Pseudoguembelina palpebra Brönnimann \& Brown 1953

Pseudotextularia cushmani Brown, 1969

Pseudotextularia elegans (Rzehak, 1891) [Cuneolina]

Pseudotextularia intermedia de Klasz 1953

Racemiguembelina fructicosa (Egger, 1899) [Gümbelina]

Racemiguembelina powelli Smith \& Pessagno, 1973

Rugoglobigerina hexacamerata Brönnimann, 1952

Rugoglobigerina milamensis Smith \& Pessagno, 1973

Rugoglobigerina pennyi Brönnimann, 1952 [Rugoglobigerina rugosa subsp.]

Rugoglobigerina rotundata Brönnimann, 1952 [Rugoglobigerina rugosa subsp.]

Rugoglobigerina rugosa (Plummer, 1926) [Globigerina]

Rugotruncana subcircumnodifer (Gandolfi, 1955) [Globotruncana circumnodifer subsp.]

\section{Selected benthonic foraminifera}

Bolivinoides australis Edgell, 1954 [Bolivinoides decorata subsp.]

Bolivinoides delicatulus Cushman, 1927 [Bolivinoides decorata subsp.]

Bolivinoides draco (Marsson, 1878) [Bolivina]

Bolivinoides giganteus Hiltermann \& Koch, 1950 [Bolivinoides decorata subsp.]

Bolivinoides miliaris Hiltermann \& Koch, 1950 [Bolivinoides draco subsp.]

Stensioeina pommerana Brotzen, 1936

\section{Manuscript received 14 August 2001 Manuscript accepted 25 January 2003}

\section{REFERENCES}

AGSO North West Shelf Study Group 1994. Deep reflections on the North West Shelf: changing perceptions of basin formation. In: Purcell, P.G. \& Purcell, R.R. (Eds), The Sedimentary Basins of Western Australia: Proceedings of the Petroleum Exploration Society of Australia Symposium: 63-76.

Apthorpe, M.C. 1979. Depositional history of the Upper Cretaceous of the Northwest Shelf, based upon Foraminifera. The APPEA Journal, 19: 74-89.

Audley-Charles, M.G. 1988. Evolution of the southern margin of Tethys (North Australian region) from early Permian to late Cretaceous. In: Audley-Charles, M.G. \& Hallam, A. (Eds), Gondwana and Tethys. Geological Society, London, Special Publications, 37: 79-100.

Audley-Charles, M.G., Ballantine, P.D. \& Hall, R. 1988. MesozoicCenozoic rift-drift sequence of Asian fragments from Gondwanaland. Tectonophysics, 155: 317-330.

Baillie, P.W., Powell, C.M., Li, Z.X. \& Ryall, A.M. 1994. The tectonic framework of Western Australia's Neoproterozoic to Recent sedimentary basins. In: Purcell, P.G. \& Purcell, R.R. (Eds), The Sedimentary Basins of Western Australia: Proceedings of the Petroleum Exploration Society of Australia Symposium: 45-62.

Barrera, E. 1994. Global environmental changes preceding the Cretaceous-Tertiary boundary: Early-late Maastrichtian transition. Geology, 22: 877-880.

Barrera, E., Savin, S.M., Thomas, E. \& Jones, C.E. 1997. Evidence for thermohaline-circulation reversals controlled by sea-level change in the latest Cretaceous. Geology, 25: 715-718. 
Bergen, J.A. \& Sikora, P.J. 1999. Microfossil diachronism in southern Norwegian North Sea chalks: Valhall and Hod fields. In: Jones, R.W. \& Simmons, M.D. (Eds), Biostratigraphy in Production and Development Geology. Geological Society, London, Special Publications, 152: 85-111.

Boersma, A. 1981. Cretaceous and Tertiary foraminifera from Deep Sea Drilling Project leg 62 sites in the Central Pacific. In: Thiede, J. \& Vallier, T.L. (Eds), Initial Reports of the Deep Sea Drilling Project, U.S. Government. Washington D.C, 377-396.

Bown, P.R. 1998. Calcareous Nannofossil Biostratigraphy. British Micropalaeontology Society Publications Series, Chapman \& Hall/ Kluwer Academic Press, 314 pp.

Bown, P.R. \& Young, J.R. 1998. Techniques. In: Bown, P.R. (Ed.), Calcareous Nannofossil Biostratigraphy. British Micropalaeontology Society Publications Series, Chapman \& Hall/Kluwer Academic Press, 16-28.

Bralower, T.J. \& Bergen, J.A. 1998. Cenomanian-Santonian calcareous nannofossil biostratigraphy of a transect of cores drilled across the Western Interior Seaway. In: Dean, W.E. \& Arthur, M.A. (Eds), Stratigraphy and paleoenvironments of the Cretaceous Western Interior Seaway, USA. SEPM concepts in sedimentology and paleontology, 6 : $59-77$.

Bralower, T.J. \& Siesser, W.G. 1992. Cretaceous calcareous nannofossil biostratigraphy of sites 761, 762, and 763 Exmouth and Wombat plateaus, Northwest Australia. Proceedings of the Ocean Drilling Program, Scientific Results, 122: 601-632.

Bukry, D. 1969. Upper Cretaceous coccoliths from Texas and Europe. The University of Kansas Paleontological Contributions, 51 (Protista 2: $1-79$.

Burnett, J.A. 1997a. New species and biostratigraphical application of Ceratolithoides Bramlette and Martini, 1964 from the Campanian and Maastrichtian of the Indian Ocean. Journal of Nannoplankton Research, 19: 123-131.

Burnett, J.A. 1997b. New species and new combinations of Cretaceous nannofossils, and a note on the origin of Petrarhabdus (Deflandre) Wind \& Wise. Journal of Nannoplankton Research, 19: 133-142.

Burnett, J.A. 1998. Upper Cretaceous. In: Bown, P.R. (Ed.), Calcareous Nannofossil Biostratigraphy. British Micropalaeontology Society Publications Series, Chapman \& Hall/Kluwer Academic Press, 132-199.

Burnett, J.A., Hancock, J.M., Kennedy, W.J. \& Lord, A.R. 1992. Macrofossil, planktonic foraminiferal and nannofossil zonation at the Campanian/Maastrichtian boundary. Newsletters on Stratigraphy, 27: 157-172.

Burnett, J.A., Kennedy, W.J. \& Ward, P. 1992. Maastrichtian nannofossil biostratigraphy in the Biscay region (south-western France, northern Spain). Newsletters on Stratigraphy, 26: 145-155.

Caron, M. 1985. Cretaceous planktic foraminifera. In: Bolli, H.M., Saunders, J.B. \& Perch-Nielsen, K. (Eds), Plankton Stratigraphy, 1: $17-86$.

Chungkham, P. \& Jafar, S.A. 1998. Late Cretaceous (SantonianMaastrichtian) integrated coccolith-globotruncanid biostratigraphy of pelagic limestones from the accretionary prism of Manipur, northeastern India. Micropaleontology, 44: 69-83.

Clarke, L.J. \& Jenkyns, H.C. 1999. New oxygen isotope evidence for long-term Cretaceous climatic change in the Southern Hemisphere. Geology, 27: 699-702.

Dalbiez, F. 1955. The genus Globotruncana in Tunisia. Micropaleontology, 1: 161-171.

Ellis, B.F. \& Messina, A.R. 1945 et seq. Catalogue of Foraminifera. Special Publication, American Museum of Natural History.

Exon, N.P., Haq, B.U. \& von Rad, U. 1992. Exmouth Plateau revisited: scientific drilling and geological framework. Proceedings of the Ocean Drilling Program, Scientific Results, 122: 3-22.

Exon, N.F., Borella, P.E. \& Ito, M. 1992. Sedimentology of marine Cretaceous sequences in the central Exmouth Plateau (northwest Australia). Proceedings of the Ocean Drilling Program, Scientific Results, 122: 233-258.

Frank, T.D. \& Arthur, M.A. 1999. Tectonic forcings of Maastrichtian ocean-climate evolution. Palaeoceanography, 14: 103-117.

Gardin, S. \& Monechi, S. 2001. Calcareous nannofossil distribution in the Tercis geological site (Landes, SW France) around the Campanian-Maastrichtian boundary. In: Odin, G.S. (Ed.), The
Campanian-Maastrichtian Boundary. Developments in Palaeontology and Stratigraphy, 19, Elsevier. Amsterdam, 272-292.

Gardin, S., Odin, G.S., Bonnemaison, M., Melinte, M., Monechi, S. \& von Salis, K. 2001. Results of the cooperative study on the calcareous nannofossils across the Campanian-Maastrichtian boundary at Tercis les Bains (Landes, France). In: Odin, G.S. (Ed.), The CampanianMaastrichtian Boundary. IUGS Special Publication (monograph) Series 36, Developments in Palaeontology and Stratigraphy, 19, Elsevier. Amsterdam, 293-309.

Glaessner, M.F. 1948. Principles of Micropaleontology, John Wiley and Sons. New York, 296 pp.

Golovchenko, X., Borella, P.E. \& O'Connell, S. 1992. Sedimentary cycles on the Exmouth Plateau. Proceedings of the Ocean Drilling Program, Scientific Results, 122: 279-291.

Gradstein, F.M., Agterberg, F.P., Ogg, J.G., Hardenbol, J., van Veen, P., Thierry, J. \& Huang, Z. 1994. A Mesozoic time scale. Journal of Geophysical Research, 99: 24051-24074.

Haq, B.U., Hardenbol, J. \& Vail, P.R. 1987. Chronology of fluctuating sea levels since the Triassic. Science, 235: 1156-1166.

Haq, B.U., von Rad, U. \& 26 others 1990. Site 761. Proceedings of the Ocean Drilling Program, Initial Reports, 12: 161-211.

Haq, B.U., von Rad, U. \& 26 others 1990. Site 762. Proceedings of the Ocean Drilling Program, Initial Reports, 122: 213-288.

Hardenbol, J. \& Robaszynski, F. 1998. Introduction to the Upper Cretaceous. In: de Graciansky, P.C., Hardenbol, J., Jacquin, T., Vail, P.R. \& Farley, M.B. (Eds), Mesozoic and Cenozoic Sequence Stratigraphy of European Basins. Society of Economic Paleontologists and Mineralogists, Special Publication, 60: 329-332.

Henricksson, A.S. 1993. Biochronology of the terminal Cretaceous calcareous nannofossil Zone of Micula prinsii. Cretaceous Research, 14: $59-68$.

Holmes, M.A. \& Watkins, D.K. 1992. Middle and Late Cretaceous history of the Indian Ocean. Synthesis of Results from Scientific Drilling in the Indian Ocean, Geophysical Monograph, 70: 225-244.

Hornibrook, N.d.B., Brazier, R.C. \& Strong, C.P. 1989. Manual of New Zealand Permian to Pleistocene Foraminiferal Biostratigraphy. New Zealand Geological Paleontological Bulletin, 56: $175 \mathrm{pp}$.

Howe, R.W., Haig, D.W. \& Apthorpe, M.C. 2000. CenomanianConiacian transition from siliciclastic to carbonate marine deposition, Giralia Anticline, Southern Carnarvon Platform, Western Australia. Cretaceous Research, 21: 517-551.

Huang, Z., Boyd, R. \& O'Connell, S. 1992. Upper Cretaceous cyclic sediments from Hole 762C, Exmouth Plateau, northwest Australia. Proceedings of the Ocean Drilling Program, Scientific Results, 122: 259-277.

Huber, B.T. 1990. Maestrichtian planktonic foraminifer biostratigraphy of the Maud Rise (Weddell Sea, Antarctica): ODP Leg 113 Holes 689B and 690C. Proceedings of the Ocean Drilling Program, Scientific Results, 113: 489-513.

Huber, B.T. 1991. Maestrichtian planktonic foraminifer biostratigraphy and the Cretaceous/Tertiary boundary at Hole 738C (Kerguelen Plateau, Southern Indian Ocean). Proceedings of the Ocean Drilling Program, Scientific Results, 114: 451-495.

Huber, B.T. 1992. Paleobiogeography of Campanian-Maastrichtian foraminifera in the southern high latitudes. Palaeogeography, Palaeoclimatology, Palaeoecology, 92: 325-360.

Huber, B.T., Hodell, D.A. \& Hamilton, C.P. 1995. Middle-Late Cretaceous climate of the southern high latitudes: Stable isotopic evidence for minimal equator-pole thermal gradients. Geological Survey of America Bulletin, 107: 1164-1191.

Ion, J. \& Odin, G.S. 2001. Preliminary study of the benthic foraminifera of the Campanian-Maastrichtian section at Tercis les Bains (Landes, France). In: Odin, G.S. (Ed.), The Campanian-Maastrichtian Boundary. IUGS Special Publication (monograph) Series 36, Developments in Palaeontology and Stratigraphy, 19, Elsevier. Amsterdam, 310-327.

Kennedy, W.J., Cobban, W.A. \& Scott, G.R. 1992. Ammonite correlation of the uppermost Campanian of Western Europe, the U.S. Gulf Coast, Atlantic Seaboard and Western Interior, and the numerical age of the base of the Maastrichtian. Geological Magazine, 129: $497-500$. 
Kennard, J.M., Deighton, I., Edwards, D.S., Colwell, J.B., O'Brien, G.W. \& Boreham, C.J. 1999. Thermal history modelling and transient heat pulses: new insights into hydrocarbon expulsion and 'hot flushes' in the Vulcan Sub-basin, Timor Sea. The APPEA Journal, 39: 177-207.

Kucera, M. \& Malmgren, B.A. 1996. Latitudinal variation in the planktic foraminifer Contusotruncana contusa in the terminal Cretaceous ocean. Marine Micropalaeontology, 28: 31-52.

MacLeod, K.G. 1994. Extinction of Inoceramid bivalves in Maastrichtian strata of the Bay of Biscay region of France and Spain. Journal of Paleontology, 68: 1048-1066.

MacLeod, K.G. 1994. Bioturbation, inoceramid extinction, and midMaastrichtian ecological change. Geology, 22: 139-142.

MacLeod, K.G. \& Huber, B.T. 1996. Reorganization of deep ocean circulation accompanying a Late Cretaceous extinction event. Nature, 380: 422-425.

McNamara, K.J., Rexilius, J.P., Marshall, N.G. \& Henderson, R.A. 1988. The first record of a Maastrichtian ammonite from the Perth Basin, Western Australia, and its biostratigraphical significance. Alcheringa, 12: 163-168.

Melinte, M. \& Odin, G.S. 2001. Optical study of the calcareous nannofossils from Tercis les Bains (Landes, France) across the Campanian-Maastrichtian boundary. In: Odin, G.S. (Ed.), The Campanian-Maastrichtian Boundary. IUGS Special Publication (monograph) Series 36, Developments in Palaeontology and Stratigraphy, 19. Elsevier, Amsterdam, 285-292.

Metcalfe, I. 1996. Gondwanaland dispersion, Asian accretion and evolution of eastern Tethys. Australian Journal of Earth Sciences, 43 605-623.

Mory, A.J. 1988. Regional geology of the offshore Bonaparte Basin. In: Purcell, P.G. \& Purcell, R.R. (Eds), The North West Shelf, Australia: Proceedings of Petroleum Exploration Society Australia Symposium, Perth, 287-310.

Müller, R.D., Mihut, D. \& Baldwin, S. 1998. A new kinematic model for the formation and evolution of the west and northwest Australian Margin. In: Purcell, P.G. \& Purcell, R.R. (Eds), The Sedimentary Basins of Western Australia 2: Proceedings of Petroleum Exploration Society Australia Symposium, Perth, 73-80.

Nederbragt, A.J. 1991. Late Cretaceous biostratigraphy and development of Heterohelicidae (planktic foraminifera). Micropaleontology, 37: 329-372.

Nederbragt, A.J. 1998. Quantitative biogeography of late Maastrichtian planktic foraminifera. Micropaleontology, 44: 385-412.

Nöel, D. 1956. Coccolithes des terrains Jurassiques de l'Algerie. Publications, Service de la Carte Geologique (Algerie), Bulletin, 8 303-345.

O'Brien, G.W., Etheridge, M.A., Willcox, J.B., Morse, M., Symonds, P., Norman, C. \& Needham, D.J. 1993. The structural architecture of the Timor Sea, North-Western Australia: implications for basin development and hydrocarbon exploration. The APPEA Journal, 33 258-277.

O'Brien, G.W., Morse, M., Wilson, D., Quiafe, P., Colwell, J., Higgins, R. \& Foster, C.B. 1999. Margin-scale, basement-involved compartmentalisation of Australia's North West Shelf: a primary control on basin-scale rift, depositional and reactivation histories. The APPEA Journal, 39: 40-63.

Odin, G.S. 1996. Definition of a Global Boundary Stratotype Section and Point for the Campanian/Maastrichtian boundary. In: Rawson, P.F. (Ed.), Second International Symposium on Cretaceous Stage Boundaries, Brussels, Sciences de la Terre Aardwetenschappen, Bulletin de l'Institut royal des Sciences naturelles de Belgique, 66-Supp: $111-117$.

Odin, G.S. 2001a. The Campanian-Maastrichtian Stage Boundary. IUGS Special Publication (monograph) Series 36, Developments in Palaeontology and Stratigraphy, 19. Elsevier, Amsterdam, $881 \mathrm{pp}$.

Odin, G.S. 2001b. Numerical age calibration of the CampanianMaastrichtian succession at Tercis les Bains (Landes, France) and in the Bottaccione Gorge (Italy). In: Odin, G.S. (Ed.), The CampanianMaastrichtian Boundary. IUGS Special Publication (monograph) Series 36, Developments in Palaeontology and Stratigraphy, 19. Elsevier, Amsterdam, 775-782.
Odin, G.S., Arz, J.A., Caron, M. \& Ion, J. 2001.et al. CampanianMaastrichtian planktonic foraminifera at Tercis les Bains (Landes, France); synthetic view and potential for global correlation. In: Odin, G.S. (Ed.), The Campanian-Maastrichtian Boundary. IUGS Special Publication (monograph) Series 36, Developments in Palaeontology and Stratigraphy, 19. Elsevier, Amsterdam, 379-395.

Pattillo, J. \& Nicholls, P.J. 1990. A tectonostratigraphic framework for the Vulcan Graben, Timor Sea region. The APEA Journal, 30: 27-51.

Perch-Nielsen, K. 1985. Mesozoic calcareous nannofossils. In: Bolli, H.M., Saunders, J.B. \& Perch-Nielsen, K. (Eds), Plankton Stratigraphy. Cambridge University Press, Cambridge, 329-426.

Pessagno, E.A. 1967. Upper Cretaceous planktonic foraminifera from the western Gulf Coastal Plain. Palaeontographica America, 5: 245-445.

Petrizzo, M.R. 2000. Upper Turonian-lower Campanian planktonic foraminifera from southern mid-high latitudes (Exmouth Plateau, NW Australia): biostratigraphy and taxonomic notes. Cretaceous Research, 21: 479-505.

Pospichal, J.J. \& Bralower, T.J. 1992. Calcareous nannofossils across the Cretaceous/Tertiary boundary, Site 761, northwest Australian margin. Proceedings of the Ocean Drilling Program, Scientific Results, 122: 735-752

Powell, C.M., Roots, S.R. \& Veevers, J.J. 1988. Pre-breakup continental extension in East Gondwanaland and the early opening of the eastern Indian Ocean. Tectonophysics, 155: 261-283.

Premoli-Silva, I. \& Sliter, W.V. 1994. Cretaceous planktonic foraminiferal biostratigraphy and evolutionary trends from the Bottaccione section, Gubbio, Italy. Palaeontographia Italica, 82: 1-89.

Premoli-Silva, I. \& Sliter, W.V. 1999. Cretaceous paleoceanography: Evidence from planktonic foraminiferal evolution. In: Barrera, E. \& Johnson, C.C. (Eds), Evolution of the Cretaceous ocean-climate system. Geological Society of America, Boulder, Special Paper, 332: 301-328.

Rexilius, J.P. 1984. Late Cretaceous foraminiferal and calcareous nannoplankton biostratigraphy, Southwestern Australian Margin. $\mathrm{PhD}$ Thesis. Department of Geology \& Geophysics, The University of Western Australia, Perth, Western Australia, 291 pp.

Risatti, J.B. 1973. Nannoplankton biostratigraphy of the upper Bluffport Marl-lower Prairie Bluff Chalk interval (upper Cretaceous), in Mississippi. In: Smith, L.A. \& Hardenbol, J. (Eds), Proceedings of a symposium on calcareous nannofossils. Society of Economic Paleontologists and Mineralogists, Gulf Coast Section, Houston, Texas, $8-57$.

Robaszynski, F., Caron, M., Donoso, J.M.G. \& Wonders, A.A.H. et al. 1984. Atlas of late Cretaceous Globotruncanids. Revue de Micropaleontologie, 26: 145-305.

Robaszynski, F. \& Caron, M. 1995. Foraminiferes planctoniques du Cretace: commentaire de la zonation Europe-Mediterranee. Bulletin de la Societe Geologique de France, 166: 681-692.

Roth, P.H. 1978. Cretaceous nannoplankton biostratigraphy and oceanography of the Northwestern Atlantic Ocean. Initial Reports of the Deep Sea Drilling Project, 44: 731-760.

Scotese, C.R., Gahagan, L.M. \& Larson, R.L. 1988. Plate tectonic reconstruction of the Cretaceous and Cenozoic ocean basins. Tectonophysics, 155: 27-48.

Shafik, S. 1990. Late Cretaceous nannofossil biostratigraphy and biogeography of the Australian western margin. Australian Bureau of Mineral Resources, Report, 295: 164 pp.

Shafik, S. 1993. Albian and Maastrichtian nannofloral biogeographic provinces in Western Australia. Australian Geological Survey Organisation Research Newsletter, 19: 15.

Shafik, S. 1998. Problems with the Cretaceous biostratigraphic system of Australia: time for a review. Australian Geological Survey Organisation Research Newsletter, 28: 12-14.

Sigal, J. 1977. Essai de zonation du Cretace mediterraneen a l'aide des foraminiferes planctoniques. Geologie Mediterranéenne, 4: 99-108.

Sissingh, W. 1977. Biostratigraphy of Cretaceous calcareous nannoplankton. Geologie en Mijnbouw, 56: 37-65.

Smith, C.C. \& Pessagno, E.A. 1973. Planktonic foraminifera and stratigraphy of the Corsicana Formation (Maestrichtian) north- 
central Texas. Cushman Foundation for Foraminiferal Research, Special Publication, 12: 68 pp.

Struckmeyer, H.I.M., Yeung, M. \& Bradshaw, M.T. 1990. Mesozoic palaeogeography of the northern margin of the Australian Plate and its implications for hydrocarbon exploration. In: Carman, G.J. \& Carman, Z. (Eds), Petroleum Exploration in Papua New Guinea: Proceedings of the First PNG Petroleum Convention: 137-152.

Thierstein, H.R. 1981. Late Cretaceous nannoplankton and the change at the Cretaceous-Tertiary boundary. In: Warme, J.E., Douglas, R.G. \& Winterer, E.L. (Eds), The Deep Sea Drilling Project: a decade of progress. SEPM Special Publication: 355-394.

Tronchetti, G. 2001. Les foraminiferes benthiques des affleurements campano-maastrichtiens de Tercis les Bains (Landes, France). In: Odin, G.S. (Ed.), The Campanian-Maastrichtian Boundary. Developments in Palaeontology and Stratigraphy, 19, Elsevier. Amsterdam, 314-327.

Tronchetti, G., Ion, J. \& Odin, G.S. 2001. Benthic foraminifera of the Campanian-Maastrichtian geological site at Tercis les Bains (France); synthesis. In: Odin, G.S. (Ed.), Developments in Palaeontology and Stratigraphy, 19, Elsevier. Amsterdam, 328-337.

van Hinte, J.E. 1976. A Cretaceous time scale. Bulletin of the American Association of Petroleum Geologists, 60: 498-516.

von Salis, K. 2001. Calcareous nannofossils around the Campanian/ Maastrichtian Boundary at Tercis, France. In: Odin, G.S. (Ed.), The Campanian-Maastrichtian Boundary. Developments in Palaeontology and Stratigraphy, 19, Elsevier. Amsterdam, 268-271.

Veevers, J.J. \& Powell, C.M. 1990. Phanerozoic tectonic regimes of Australia reflect global events. Journal of Structural Geology, 12 $545-551$.

Veevers, J.J., Powell, C.M. \& Roots, S.R. 1991. Review of seafloor spreading around Australia. I. Synthesis of the patterns of spreading. Australian Journal of Earth Sciences, 38: 373-389.

von Rad, U. \& Bralower, T.J. 1992. Unique record of an incipient ocean basin: Lower Cretaceous sediments from the southern margin of Tethys. Geology, 20: 551-555.

von Rad, U., Exon, N.F. \& Haq, B.U. 1992. Rift-to-drift history of the Wombat Plateau, northwest Australia: Triassic to Tertiary Leg 122 results. Proceedings of the Ocean Drilling Program, Scientific Results, 122: $765-800$.

Ward, P.D. \& Kennedy, W.J. 1993. Maastrichtian ammonites from the Biscay Region (France, Spain). Journal of Paleontology, Supplement, 67: $1-58$.

Watkins, D.K., Wise, S.W. Jr, Pospichal James, J. \& Crux, J. 1996. Upper Cretaceous calcareous nannofossil biostratigraphy and paleoceanography of the Southern Ocean. In: Moguilevsky, A. \& Whatley, R. (Eds), Microfossils and oceanic environments, University of Wales, Aberystwyth Press, 355-381.

Webb, P.N. 1973. Upper Cretaceous-Paleocene foraminifera from Site 208 (Lord Howe RiseTasman Sea), DSDP, Leg 21. In: Burns, R.E. \& Andrews, J.E. (Eds), Initial Reports of the Deep Sea Drilling Project, Leg21, US Government Printing Office. Washington D.C, $541-573$.

Wonders, A.A.H. 1980. Middle and Late Cretaceous planktonic Foraminifera of the Western Mediterranean area. Utrecht Micropaleontology Bulletin, 24: 1-158.

Wonders, A.A.H. 1992. Cretaceous planktonic foraminiferal biostratigraphy, Leg 122, Exmouth Plateau, Australia. Proceedings of the Ocean Drilling Program, Scientific Results, 122: 587-599.

Wright, C.A. \& Apthorpe, M. 1976. Planktonic foraminiferids from the Maastrichtian of the Northwest Shelf, Western Australia. Journal of Foraminiferal Research, 6: 228-241.

Wright, C.A. \& Apthorpe, M. 1995. C.A. Wright's Cretaceous planktonic foraminiferal zonation for the Northwest Shelf, Australia. (abstract) Second International Symposium on Cretaceous Stage Boundaries, Institut Royal des Sciences Naturelles de Belgique. Brussels, 128.

Young, J.R., Bergen, J.A. \& Bown, P.R. et al. 1997. Guidelines for coccolith and calcareous nannofossil terminology. Palaeontology, 40(4): 875-912.

Zepeda, M.A. 1998. Planktonic foraminiferal diversity, equitability and biostratigraphy of the uppermost Campanian - Maastrichtian, ODP Leg 122, Hole 762C, Exmouth Plateau, NW Australia, eastern Indian Ocean. Cretaceous Research, 19: 117-152. 